\title{
Clinopyroxene episyenites in a Proterozoic rapakivi granite, SE Finland - recrystallization textures, mass transfer and implications for the petrology of A-type granite complexes
}

\author{
Einari Suikkanen ${ }^{1}$ (D) $\cdot$ O. Tapani Rämö ${ }^{1} \cdot$ Timo Ahtola $^{2} \cdot$ Panu Lintinen $^{3}$ \\ Received: 10 August 2018 / Accepted: 19 August 2019/Published online: 31 August 2019 \\ (C) The Author(s) 2019
}

\begin{abstract}
Na-metasomatic augite and aegirine-augite episyenites are hosted by subalkaline amphibole granites in the $1.644 \mathrm{Ga}$ Suomenniemi rapakivi granite complex, southeastern Finland. In an examined drill core, episyenites are bordered by up to 50$\mathrm{cm}$-wide zones of $\mathrm{Na}$-enriched augite-bearing granite in which alkali feldspar forms rims on plagioclase, and aggregates of augite and magnetite have formed by fluid-induced dehydration of hastingsite and biotite. In the episyenites, quartz has been partially removed, alkali feldspar $\left(\mathrm{An}_{<1} \mathrm{Ab}_{50} \mathrm{Or}_{50}\right)$ and plagioclase have been partially recrystallized to granoblastic polygonal aggregates, and clinopyroxene (augite or aegirine-augite) has coarsened and been enriched in the aegirine component. Mass balance modeling implies addition of mainly $\mathrm{Na}$, depletion of $\mathrm{Si}, \mathrm{F}, \mathrm{Rb}, \mathrm{Ba}, \mathrm{Sr}$ and $10-20 \%$ volume loss (by quartz dissolution) in the episyenitized zones in the drill core. Quartz-depletion and recrystallization may have been caused by several superimposed stages of alteration, probably related to voluminous dike- and A-type granite magmatism in the Suomenniemi area 10-15 m.y. after the emplacement of the Suomenniemi complex. Because of the coarse recrystallization textures and near-solidus recrystallization temperatures, distinguishing these fenite-like metasomatic rocks from igneous syenites is not trivial. In epizonal A-type granite complexes, high-temperature episyenites may be more common than currently thought.
\end{abstract}

Keywords Episyenite $\cdot$ A-type granite $\cdot$ Syenite $\cdot$ Na-metasomatism $\cdot$ Deformation $\cdot$ Recrystallization $\cdot$ Finland

\section{Introduction}

Episyenites are hydrothermally altered granitic rocks formed by dissolution of quartz by magmatic or meteoric fluids (Cathelineau 1986; Charoy and Pollard 1989). Typically, they form small bodies along (inferred) fault zones in the upper crust,

Editorial handling: C. Hauzenberger

Electronic supplementary material The online version of this article (https://doi.org/10.1007/s00710-019-00684-w) contains supplementary material, which is available to authorized users.

Einari Suikkanen

einari.suikkanen@helsinki.fi

1 Department of Geosciences and Geography, University of Helsinki, Helsinki, Finland

2 Geological Survey of Finland, Espoo, Finland

3 Geological Survey of Finland, Rovaniemi, Finland with numerous documented occurrences in France (Leroy 1978), Germany (Hecht et al. 1999), Sweden (Petersson et al. 2014; Petersson et al. 2012) and Ukraine (Cuney et al. 2012), for example. Solubility of silica in aqueous fluids may increase with fluid alkalinity (Akinfiev and Diamond 2009), and episyenitization is usually related to sodium metasomatism (e.g. Charoy and Pollard 1989). Quartz-depleted syenitic rocks are also found in alkali-metasomatized (fenitic) aureoles of alkaline intrusions and carbonatites (Le Bas 1987). Fenites are characterized by metasomatic aegirine-augite (that may replace quartz) and alkali feldspar. While episyenitization typically results in a vuggy rock with variable hydrothermal cavity fillings, fenites may have undergone extensive recrystallization to the point where they resemble igneous syenites (e.g., Vartiainen and Woolley 1976).

Pervasively recrystallized, Na-metasomatic episyenites are hosted by granites of the $1.644 \mathrm{Ga}$ A-type Suomenniemi rapakivi complex in southeastern Finland (Suikkanen and Rämö 2017). High metasomatic temperatures $\left(>650^{\circ} \mathrm{C}\right.$ estimated from alkali feldspar compositions), stabilization of 
secondary clinopyroxene and pervasive recrystallization of the subalkaline granites are, however, rarely described in episyenites (cf. González-Casado et al. 1996), instead resembling fenitization (Le Bas 1987). In addition, due to the absence of an obvious fluid source and coarse recrystallization textures present in these high-temperature episyenites, their metamorphic origin is easily masked and they may be misinterpreted as magmatic rocks.

This work is based on a novel drill core that penetrates episyenites and their host granites in the eastcentral part of the Suomenniemi complex (Fig. 1). Spatially controlled examination of these clinopyroxenebearing episyenites and their altered granitic margins allows us to model the geochemical mass transfer processes and mineralogical evolution of these rocks to understand the genesis of the high-temperature episyenites in A-type granite complexes. We have used optical petrography, whole-rock geochemistry and isocon analysis (Grant 1986), and electron microprobe analysis of rockforming silicates on a comprehensive set of samples recovered from the Suomenniemi drill core. The results of this contribution suggest that episyenitization and high- temperature recrystallization may lead to formation of diverse, distinctly metasomatic, syenitic rocks in A-type granite complexes.

\section{Geological setting and target of research}

The epizonal 1.644 Ga Suomenniemi rapakivi granite complex in southeastern Finland comprises a series of subalkaline amphibole, biotite-amphibole, biotite, and topaz granites (Rämö 1991; Rämö and Mänttäri 2015; Fig. 1). Minor fayalite-clinopyroxene-amphibole granite bodies (ca. $1.635 \mathrm{Ga}$ ) and NW-striking diabase and quartz-feldspar porphyry dikes (ca. $1.635 \mathrm{Ga}$ ) cut the complex and the surrounding $\sim 1.9$ Ga Svecofennian bedrock. The Wiborg rapakivi granite batholith to the south of the Suomenniemi complex (Fig. 1) was emplaced at $\sim 1.63 \mathrm{Ga}$ (Heinonen et al. 2016).

Episyenites are found in the east-central part of the Suomenniemi complex (Fig. 1). They form NW-striking, irregular dike- or pod-like bodies in a $\sim 25 \mathrm{~km}^{2}$ area around Lake Kuolimo (Fig. 1c). Based on textural and mineralogical analysis of outcrop samples, Suikkanen and
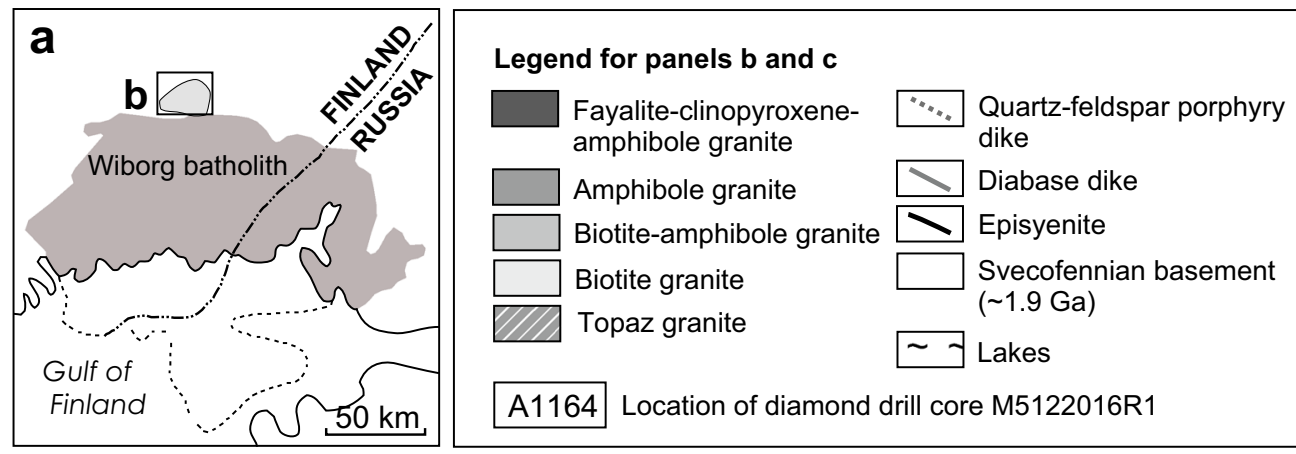

A1164 Location of diamond drill core M5122016R1

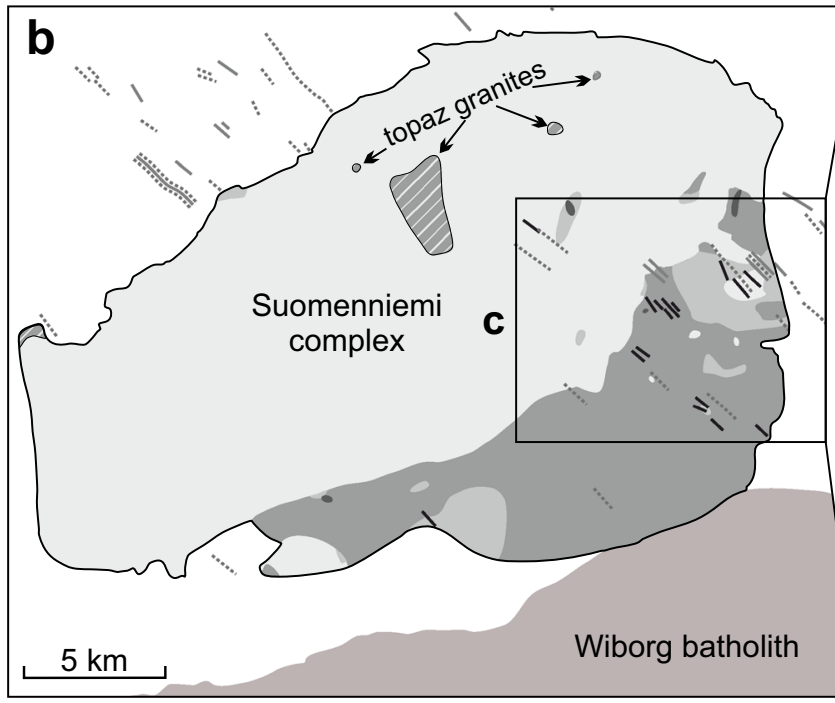

Fig. 1 a: Location of the Suomenniemi complex and the Wiborg rapakivi granite batholith relative to southeastern Finland. b: Geological map of the Suomenniemi complex. c: Geological map of the east-central part of the Suomenniemi complex (Kirvesniemi area) and the location of the drill

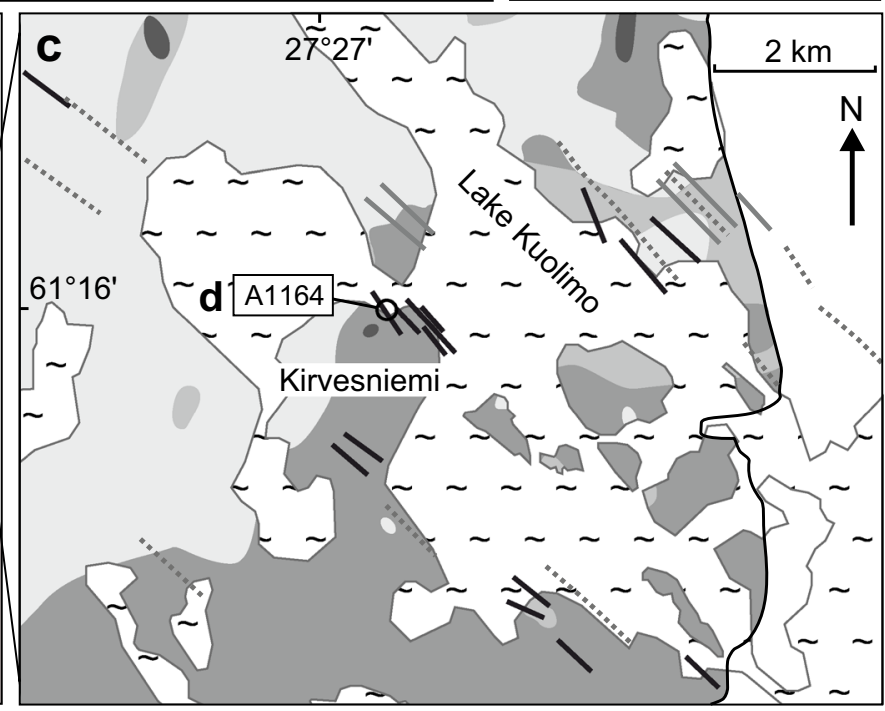

core examined in this work. $\mathbf{d}$ : Outcrop sketch showing the structure of the exposed alkali-feldspar syenitic episyenite (A1164) at the drill site (episyenite marked with horizontal stripes and amphibole granite in grey). Modified from Rämö (1991) and Suikkanen and Rämö (2017) 
Rämö (2017) noted the intimate association of the episyenites with the surrounding granites, suggesting that they were formed from the granites by quartz depletion and alkali metasomatism caused by sodic, oxidizing fluids. High metasomatic temperatures and mineralogical parallels to fenitization led Suikkanen and Rämö (2017) to further suggest hidden alkaline magmatism as the fluid source, though no evidence of spatially connected alkaline magmas has been observed.

On outcrop, five types of episyenite were distinguished by Suikkanen and Rämö (2017) based on specific mineral assemblages: (1) Calcic amphibole (hastingsite, ferro-ferrihornblende, ferro-actinolite), albite and K-feldspar; (2) calcic amphibole (hastingsite), aegirine-augite, riebeckite, albite and K-feldspar; (3) aegirine-augite, albite and Kfeldspar; (4) sodian augite-aegirine-augite and perthite; and (5) sodian augite or aegirine-augite and albite. (1) and (2) contain relict igneous minerals (hastingsite, K-feldspar, ilmenite, zircon, apatite), while the other types are pervasively recrystallized (Suikkanen and Rämö 2017). Irrespective of the extent of recrystallization, preservation of igneous zircon is suggested by single grain $\mathrm{U}-\mathrm{Pb}$ ages (ca. $1.645 \mathrm{Ga}$; Suikkanen and Rämö 2017; see also Rämö and Mänttäri 2015) and $\delta^{18} \mathrm{O}_{\text {VSMOw values (ca. 8\%o; }}$ Suikkanen and Rämö 2017; Elliott et al. 2005). Furthermore, whole-rock $\varepsilon \mathrm{Nd}(\mathrm{t})$ values of the granites and episyenites are indistinguishable (ca. -1.5; Rämö 1991; Suikkanen and Rämö 2017).

Because of poor exposure and/or limited accessibility, the outcrops examined by Suikkanen and Rämö (2017) failed to provide clear spatial control of the position and petrologic significance of the Suomenniemi episyenites. The new drill core examined in this work allows modeling of the episyenitization process in situ.

\section{Materials and methods}

\section{Drill core}

A 150-m-long diamond drill hole (M5122016R1; core diameter $4 \mathrm{~cm}$; Fig. 2) was drilled at a 45-degree angle beneath one of the more prominent episyenite bodies of the complex (A1164; Suikkanen and Rämö 2017; Fig. 1d). Two episyenite bodies were found in the drill core: a syenitic episyenite (segment a, Fig. 2) and a quartz alkali-feldspar syenitic episyenite (segment b, Fig. 2). The quartz alkali-feldspar syenitic episyenite is cut by an alkali-feldspar granite aplite (ca. $30 \mathrm{~cm}$ wide). The episyenites are surrounded by red to dark green amphibole granite that comprises most of the drill core. These rock types were sampled for petrographic, mineral chemical and geochemical analysis.

\section{Petrography and cathodoluminescence imaging}

Textures of the episyenites and their host granite were studied from polished drill core samples (Fig. 3). In addition, for petrographic and mineral chemical analysis, polished thin sections were made of relevant sections throughout the drill core (Fig. 2). Mineralogy of 26 thin section samples from the drillcore episyenite bodies, the host granite of the episyenites and the alkali-feldspar granite aplite were studied using a polarizing microscope. Most of the studied thin section samples come from the assumed continuation of the exposed episyenite body A1164 and surrounding granite at 101$105.65 \mathrm{~m}$ (Fig. 2). Relative abundances of major minerals in the thin section samples were calculated from thin section photographs using the ImageJ image processing software (Schneider et al. 2012). Cathodoluminescence (CL) imaging was used for recognition of luminescent accessory phases (calcite, apatite, and fluorite). CL imaging was carried out at the University of Helsinki using a Lumic HC6-LM hot cathode CL microscope.

\section{Electron microprobe analysis and scanning electron microscopy}

Electron microprobe analysis (EMPA) of amphibole, pyroxene, feldspar and Fe-Ti-oxides was done from polished and carbon-coated thin sections for nine samples across the syenitic episyenite body and its surrounding granite. Amphibole, pyroxene, feldspar and garnet were analyzed for two samples from the alkali-feldspar syenitic episyenite body and for one sample from the alkali granite aplite. The EMPA analytical work was done using a Cameca SX 100 microprobe at the Geological Survey of Finland with natural and synthetic silicates and oxides used as standards. Element-specific detection limits, analyzed lines and standards used are given in Online Resource 1. Electron beam current and accelerating voltage were kept at $20 \mathrm{nA}$ and $15 \mathrm{kV}$, respectively. To ensure accuracy and representability of the analyses, the beam diameter was ca. $10 \mu \mathrm{m}$ for cryptoperthite (for bulk perthite analysis), $5 \mu \mathrm{m}$ for other silicate minerals and $1 \mu \mathrm{m}$ for Fe-Tioxides. Results were calculated from up to six duplicate analyses for each data point, and $\mathrm{Fe}^{3+}$ was calculated by stoichiometry for the ferromagnesian silicates and oxides. The amphibole classification spreadsheet compiled by Locock (2014) was utilized in calculating amphibole formulae, while garnet formulae were calculated according to Grew et al. (2013).

Main carriers of rare earth elements were identified from one sample of the syenitic episyenite using the JEOL JSM$7100 \mathrm{~F}$ field emission scanning electron microscope (FESEM) at the Geological Survey of Finland. The FE-SEM was equipped with the Oxford Instruments X-Max energy dispersive spectrometer (EDS). The FE-SEM was run in high 


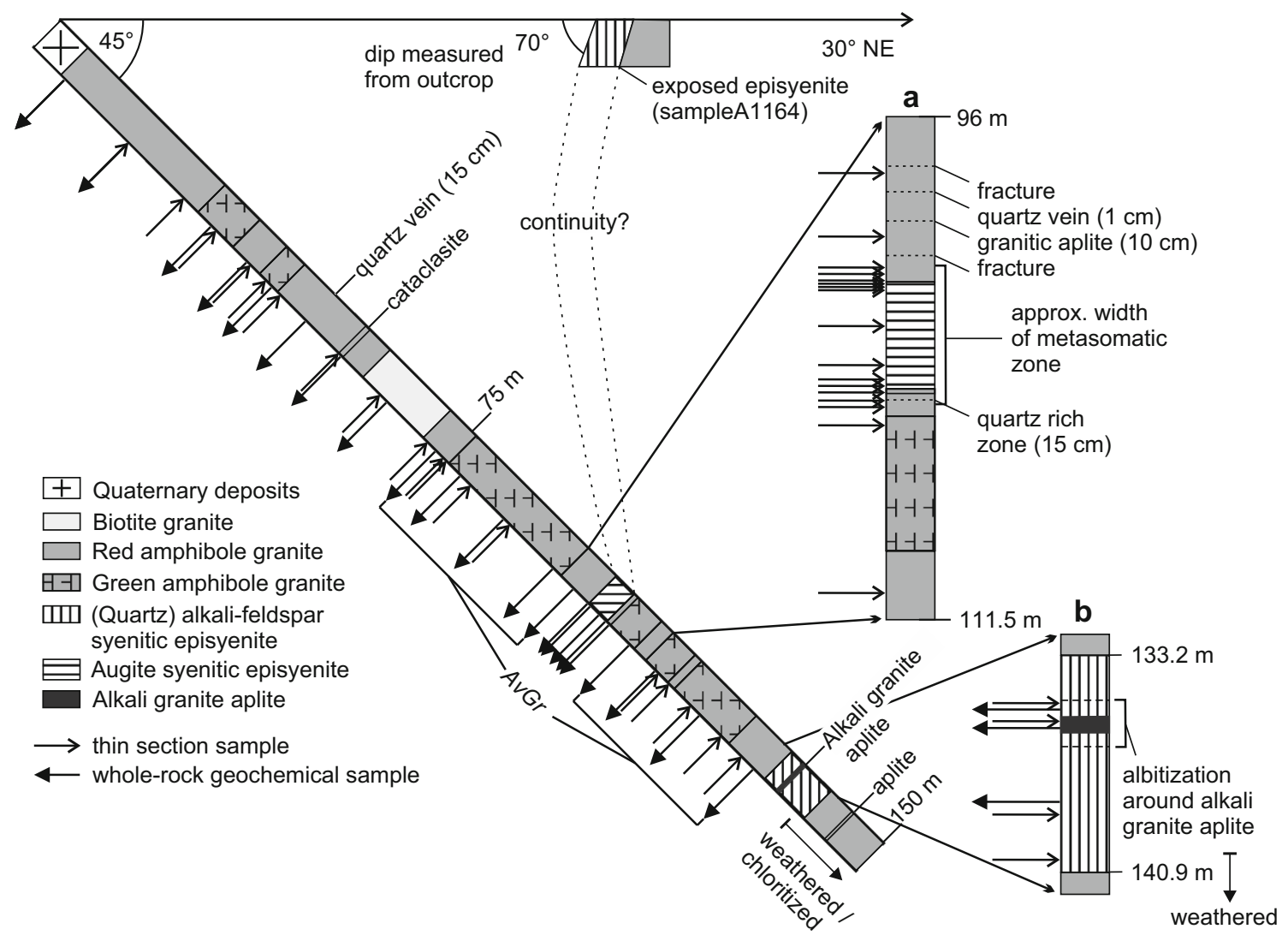

Fig. 2 Log of the diamond drill core (M5122016R1) in the east-central part of the Suomenniemi complex (drill site location is at N61 ${ }^{\circ} 15^{\prime} 56.77^{\prime \prime}$ E27 $\left.{ }^{\circ} 27^{\prime} 55.76^{\prime \prime}\right)$. The drilling was carried out at a 45 degree angle perpendicular to the dike-like alkali-feldspar syenitic episyenite body A1164 exposed in a near-shore skerry in Kirvesniemi (Suikkanen and Rämö 2017; Fig. 1). The drill core penetrates two episyenite bodies and an alkali granite aplite dike in the deeper episyenite body. The inset in upper right (segment a) shows the section from 96 to $111.5 \mathrm{~m}$ in more

vacuum mode and using an acceleration voltage of $20 \mathrm{kV}$ and a beam current of ca. $1 \mathrm{nA}$. A carbon coated thin section was scanned for all grains larger than $5 \mu \mathrm{m}$ and more dense than zircon; pertinent phases were then qualitatively identified.

\section{Whole-rock geochemistry}

Twenty-five whole-rock samples (five episyenites, one alkalifeldspar granite aplite, 19 granites) were analyzed for major and trace elements. The selected drill-core samples were crushed with a Mn-steel jaw crusher and pulverized in a tungsten carbide bowl. Major element data were acquired at the University of Helsinki using X-ray fluorescence analysis. A lithium metaborate-lithium tetraborate flux was used in preparing fused bead samples. The beads were measured on a PANalytical Axios mAX $4 \mathrm{~kW}$ wavelength dispersive X-ray fluorescence spectrometer operated with PANalytical SuperQ 5.3 software. Classic matrix model calibration was applied using a blank flux sample and 42 certified reference material standards. The precision of major element oxides is less than detail, with the approximate width of the metasomatic zone shown. The inset in lower right (segment $b$ ) shows approximate width of the albitized zone around the sodic aplite that cuts the quartz alkali-feldspar syenitic episyenite. Location of samples examined for petrography and geochemistry is marked on the log with arrows. AvGr marks the position of 10 geochemical samples of amphibole granite used to calculate the average granite composition for mass balance modeling

$0.1 \%$. Trace element and $\mathrm{F}$ analyses were performed by an accredited commercial laboratory (Labtium Co., Espoo, Finland) using inductively-coupled plasma mass spectrometry (method $306 \mathrm{M}$ ), inductively-coupled plasma optical emission spectrometry (method 306P; for $\mathrm{Li}, \mathrm{Sc}, \mathrm{Sr}, \mathrm{Y}, \mathrm{Zn}, \mathrm{Zr}$ ), and ionselective electrode analysis (method 725I) for F.

\section{Results}

\section{Petrography and mineral chemistry}

Descriptions of the rock types observed in the drill core are given below. Figure 3 shows photographs of relevant, polished drill core samples, including amphibole granite and cataclastic amphibole granite (Figs. 3a, b and c), metasomatized augite-bearing granite and episyenite (Figs. 3d, e, f and g) and alkali granite aplite (Fig. 3h). Microtextural features of the analyzed samples are depicted in Fig. 4 for granite and metasomatized granite and in Fig. 5 for the episyenites and alkali granite aplite. 

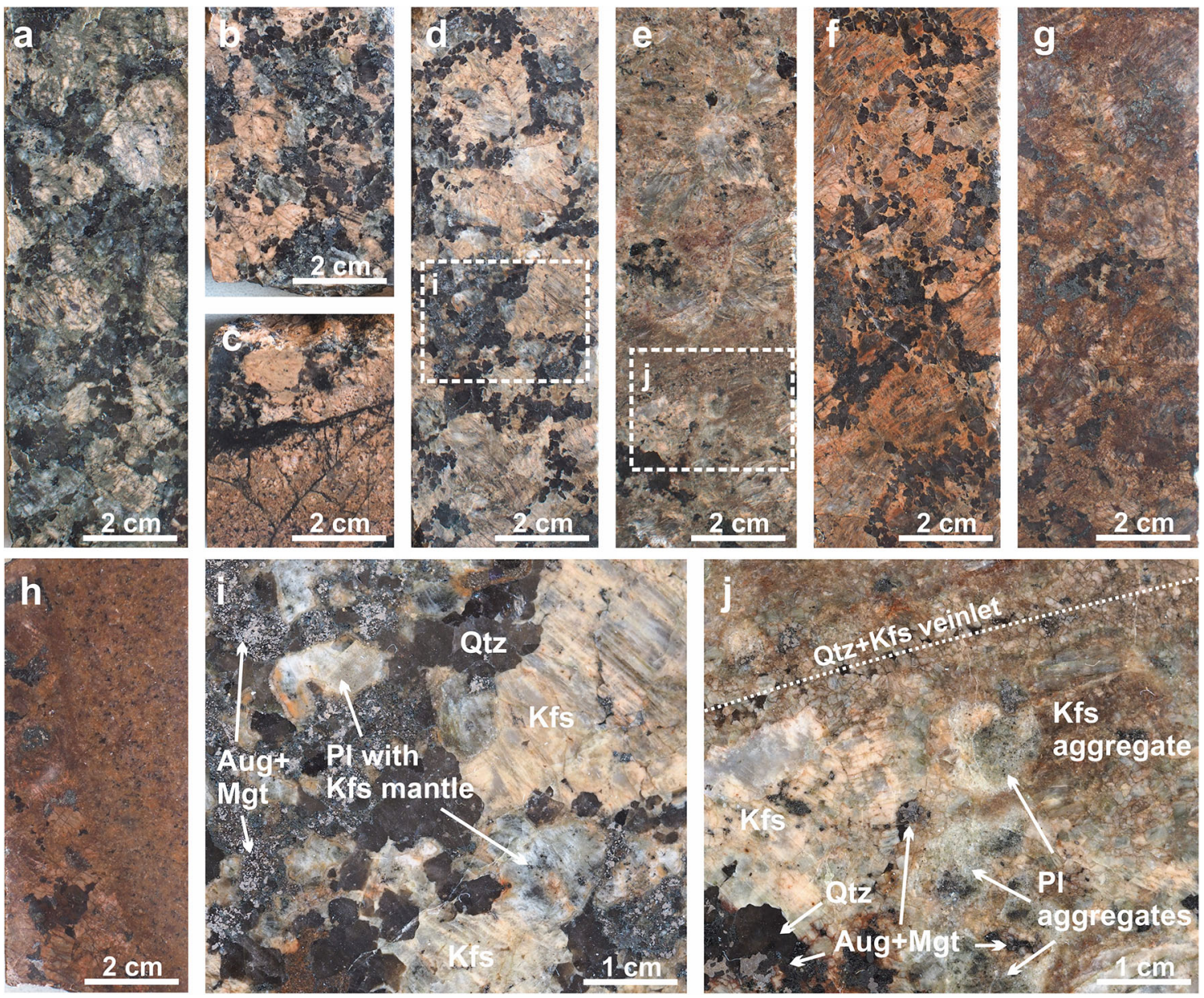

Fig. 3 a-g: Polished samples of the rock types found in the drill core and their positions in the drill core. $\mathbf{i}-\mathbf{j}$ : Notable petrographic details from the syenitic episyenite and its altered granitic margin. a: Green amphibole granite $(94.2 \mathrm{~m})$. b: Pink amphibole granite $(98.5 \mathrm{~m})$. c: Cataclastic section of the pink amphibole granite $(97.6 \mathrm{~m})$. d: Metasomatized, augite-bearing granite adjacent to the syenitic episyenite body $(104.75 \mathrm{~m})$. e: Syenitic episyenite $(102.6 \mathrm{~m})$. f: Metasomatized granite adjacent to the quartz alkali-feldspar syenitic episyenite body $(133 \mathrm{~m}) . \mathbf{g}$ : Quartz alkali-feldspar syenitic episyenite $(133.5 \mathrm{~m})$. h: Contact of the alkali granite aplite and quartz alkali-feldspar syenitic episyenite

(135.7 m). i: Closeup of the metasomatized granite shows plagioclase mantled with K-feldspar and augite-magnetite aggregates formed after amphibole. j: Closeup view of the syenitic episyenite shows mainly alkali feldspar both as fine $(0.1-1 \mathrm{~mm})$ recrystallized polygonal crystals and larger irregular grey grains. White, recrystallized aggregates of plagioclase are present. Quartz is present with augite and magnetite. A quartz veinlet bordered by alkali feldspar, which is possibly a healed quartz-filled fracture, is also shown. Abbreviations: $\mathrm{Ab}=\mathrm{Albite}, \mathrm{Aug}=$ Augite, $\mathrm{Kfs}=\mathrm{K}$-feldspar, Mgt = Magnetite, $\mathrm{Pl}=$ Plagioclase, $\mathrm{Qtz}=$ Quartz

Results of mineral chemical analyses are depicted in Figs. 6, 7 and 8 and described below. The compositions of feldspars in the granite, metasomatized granite and episyenites from the drill core are shown in an An-Ab-Or ternary diagram (Fig. 6). Amphibole compositions are shown on classification diagrams for calcium and sodium amphiboles in Fig. 7. Compositions of clinopyroxene from the drill core samples are projected in the Ae-Di-Hd ternary diagram and the composition of calcium clinopyroxene are shown in the Hd-Di-En-Fs-quadrilateral diagram in Fig. 8. Our complete mineral chemical data are available in Online Resource 1, which also includes calculated formulae of alkali feldspar, plagioclase, amphibole, clinopyroxene and garnet of representative electron microprobe analyses.

\section{Amphibole granite}

The granite hosting the episyenite bodies in the drill core is a green (Fig. 3a) to pale pink (Fig. 3b) amphibole granite with 45 65\% K-feldspar, $15-35 \%$ quartz, 3-12\% oligoclase and 3-5\% hastingsite (Fig. 4b; Fig. 7). Less than $5 \%$ of biotite and/or fayalite may be present, and ferro-actinolite (Fig. 7), fluorite, zircon, ilmenite and magnetite are the observed accessory minerals. K-feldspar forms large subhedral grains $(1-3 \mathrm{~cm})$ with composition from $\mathrm{An}_{1} \mathrm{Ab}_{30} \mathrm{Or}_{69}$ to $\mathrm{An}_{1} \mathrm{Ab}_{37} \mathrm{Or}_{62}$ (Fig. 6a). Quartz forms smaller $(<0.5 \mathrm{~cm})$ drop-shaped or subhedral grains typical of rapakivi granite (Fig. 4a), as well as anhedral inclusions in K-feldspar. Quartz and K-feldspar may show undulatory extinction. Oligoclase forms subhedral-euhedral crystals $(\sim 0.5$ $1 \mathrm{~cm}$ ) that display compositional zoning with 25-30 mol\% An 
Fig. 4 Photomicrographs of the amphibole granite (a-b) and the metasomatized granitic margins of the episyenite bodies $(\mathbf{c}-\mathbf{f})$. Crossed polarizers. a: Typical texture of the amphibole granite with subhedral plagioclase, quartz and perthitic K-feldspar. b: Chessboard albite has formed on the margin of K-feldspar crystal. c: Dehydrated granitic margin of the syenitic episyenite ca. $40 \mathrm{~cm}$ from the granite-episyenite boundary shows magnetite mantled by augite. Plagioclase has a continuous mantle of $\mathrm{K}$ feldspar. d: Aggregate of magnetite and augite within a Kfeldspar phenocryst about $10 \mathrm{~cm}$ from to the episyenite-granite boundary. Partial recrystallization of K-feldspar (Kfs1) to polygonal crystals (Kfs2) can be seen. e: Close to the episyenite body plagioclase is surrounded by polygonal crystals of perthitic Kfeldspar. Fine augite and magnetite form a granular aggregate next to quartz. f: Close to the episyenite body polygonal grains (P12) have formed on margin of plagioclase (P11). Abbreviations: $\mathrm{Ab}=$ Albite, Aug $=$ Augite, Fac $=$ Ferroactinolite, Hst $=$ Hastingsite, $\mathrm{Kfs}=\mathrm{K}$-feldspar, $\mathrm{Mgt}=$ Magnetite, $\mathrm{Pl}=$ Plagioclase, $\mathrm{Qtz}=$ Quartz, Tit $=$ Titanite, $\mathrm{Zrc}=\mathrm{Zircon}$
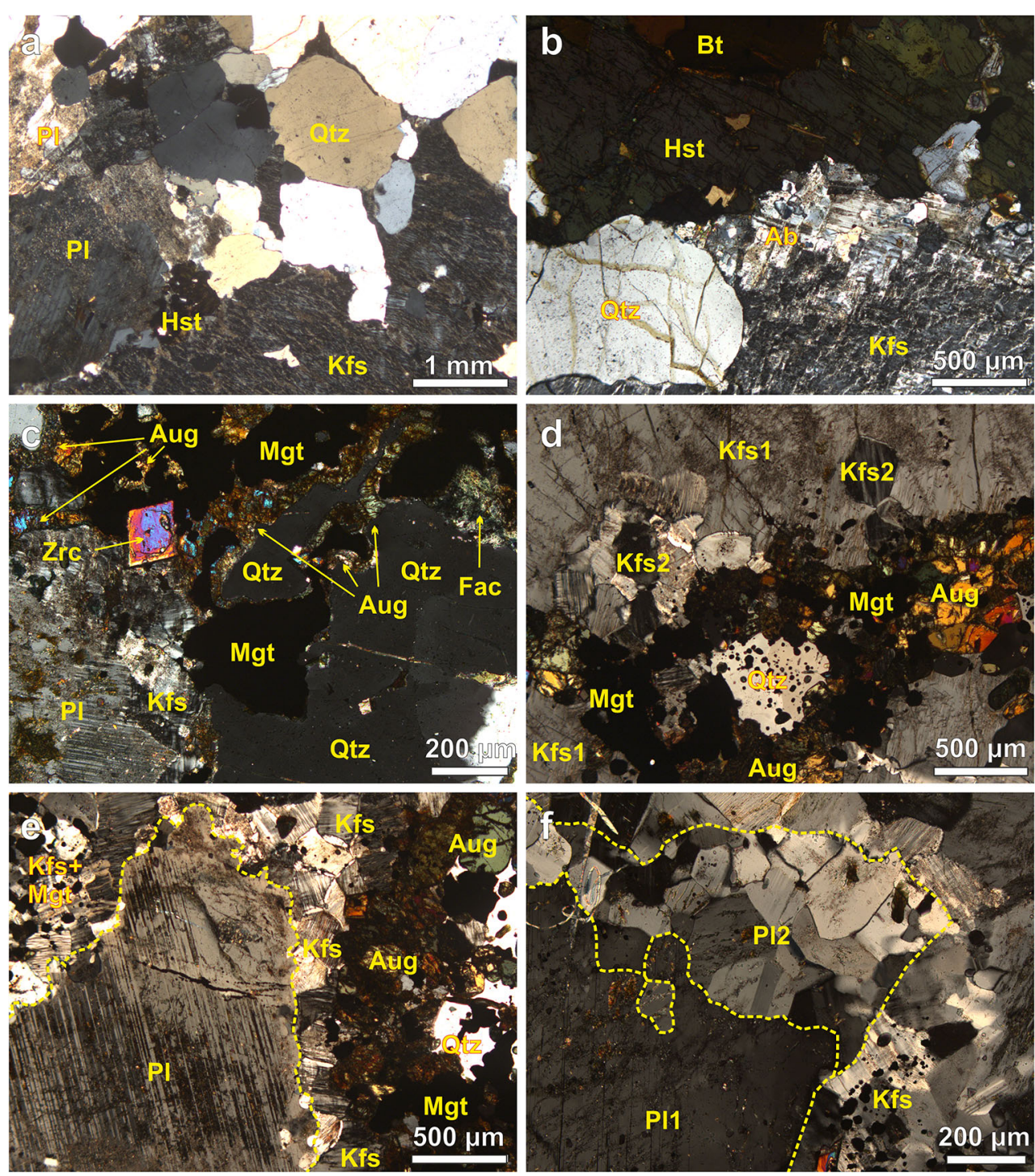

in the cores and 18-25 mol\% An in the rims (Fig. 6a). Amphibole and biotite are subhedral or interstitial, and scarcely included in K-feldspar. Fayalite is euhedral.

The amphibole granite shows common sub-solidus changes including partial replacement of K-feldspar by (cross-hatched) microcline vein perthite and scarce replacement of K-feldspar with chessboard albite (Fig. 4b). Plagioclase shows seriticization or growth of mossy green aggregates (probably mainly chlorite) along twin boundaries. The color of the green amphibole granite (Fig. 3a) is caused by alteration of alkali feldspar along fractures, grain boundaries or cleavage planes. Fayalite is mostly altered to magnetite and iddingsite. Small amounts of calcite are found in altered plagioclase and in fine fractures. Thin (1-3 $\mu \mathrm{m})$ veinlets of secondary chlorite are commonly present. Trails of fluid inclusions stripe the K-feldspar and quartz, and K-feldspar often has turbid margins.

\section{Cataclastic amphibole granite}

Cataclastic zones and fractures are present in the amphibole granite (Figs. 2 and 3c) and show micrographic intergrowths of alkali feldspar and quartz. The K-feldspar shows partial chessboard-style albitization, and the plagioclase shows extensive albitization and contains fluorite or chlorite inclusions. Fine recrystallized alkali feldspar and quartz fill fractures with chlorite. Unstrained quartz forms veinlets, in some cases with epidote. Biotite is heavily chloritized and fresh amphibole is rare in the examined samples.

\section{Metasomatized augite-bearing granite}

The episyenite bodies are surrounded by $30-50 \mathrm{~cm}$ wide zones of metasomatized granite with several distinct alteration features (Fig. 3d and f). The composition of alkali feldspar in 
Fig. 5 Features of the syenitic episyenite (a-d), quartz alkalifeldspar syenitic episyenite (e) and the alkali granite aplite $(\mathbf{f}-\mathbf{g})$. Crossed polarizers. a: K-feldspar (Kfs1) has recrystallized to polygonal aggregates (Kfs2) along grain boundaries and fractures. b: Plagioclase has recrystallized to a granoblastic aggregate. c: Rim of augite crystals along the margin of a Kfeldspar aggregate. d: Augite and magnetite within a K-feldspar aggregate, surrounding a small pool of quartz and magnetite. Magnetite is mantled by titanite. e: Aegirine-augite replaces quartz along grain boundaries in quartz alkali-feldspar syenitic episyenite. f: Subhedral-euhedral albite crystals and interstitial quartz characterize the alkali granite aplite. g: The quartz alkalifeldspar syenitic episyenite has nearly completely altered to albite on the margin of the alkali granite aplite. Abbreviations: Agt $=$ Aegirine-augite, $\mathrm{Ap}=$ Apatite, Aug = Augite, Kfs = K-feldspar, $\mathrm{Mgt}=$ Magnetite, $\mathrm{Pl}=$

Plagioclase, $\mathrm{Qtz}=$ Quartz, $\mathrm{Zrc}=$ Zircon
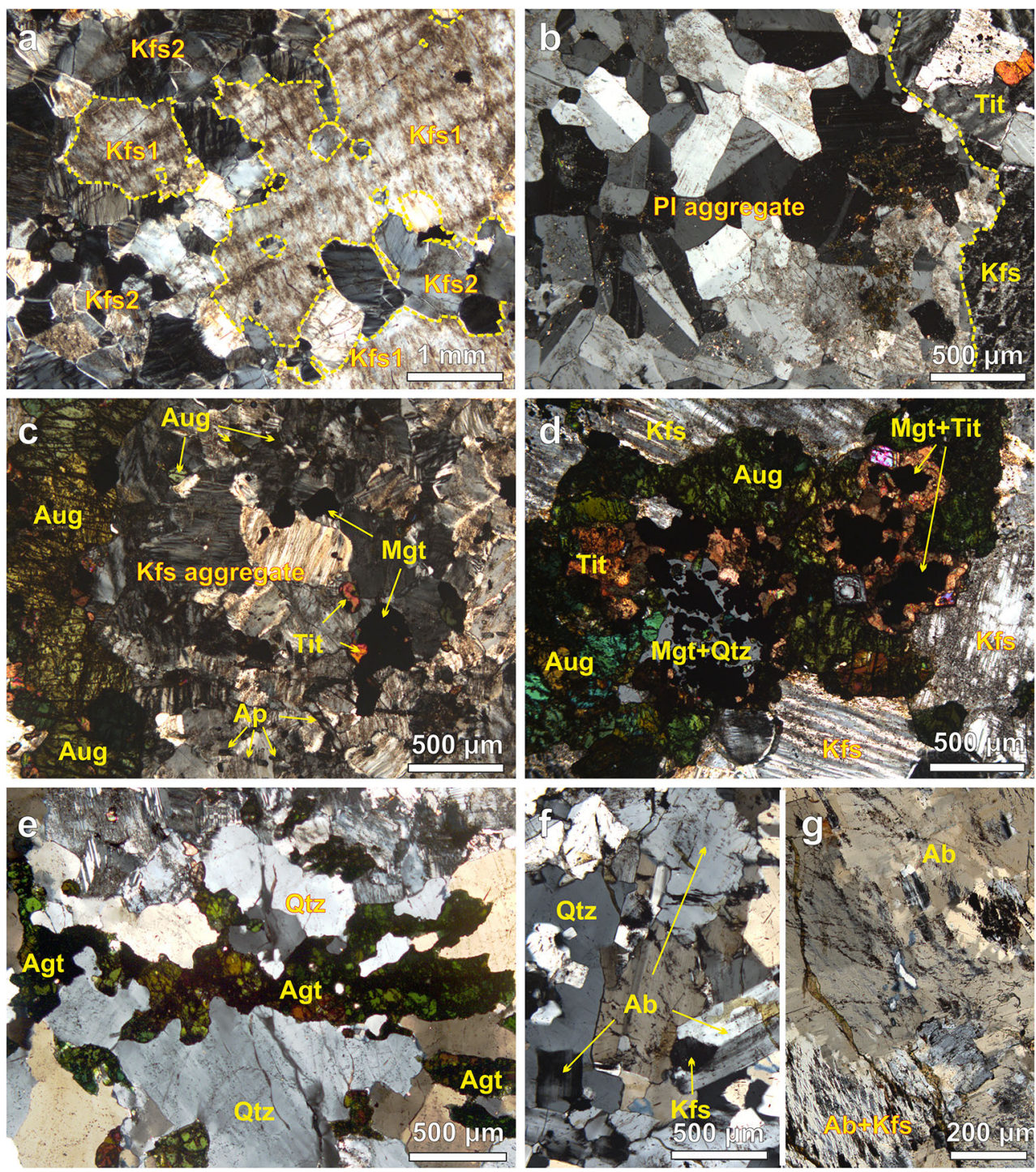

these metasomatized granites ranges from $\mathrm{An}_{<0.5} \mathrm{Ab}_{32} \mathrm{Or}_{68}$ to intermediate composition of $\mathrm{An}_{1} \mathrm{Ab}_{51} \mathrm{Or}_{48}$ close to the granite-episyenite boundary (Fig. 6a). Green augite (0-3\%) with the average composition of $\mathrm{Wo}_{44} \mathrm{En}_{7} \mathrm{Fs}_{49}(\mathrm{Na}=0.043$ apfu; Fig. 8a) forms aggregates with magnetite (Figs. 3i, 4c, $\mathrm{d}$ and $\mathrm{e}$ ), and is often associated with fluorite and feldspars; these aggregates form presumably due to hastingsite or biotite dehydration as hastingsite or biotite are scarce where augite is present. Rims of perthitic K-feldspar (polygonal crystals or continuous rims) on the plagioclase-quartz grain boundaries are ubiquitous (Fig. $4 \mathrm{~d}$ and e). Close to the granite-episyenite boundary, oligoclase has thin rims of Ca-rich albite $\left(\sim \mathrm{An}_{9}\right)$ and starts to recrystallize as polygonal grains (Fig. 4f). Titanite, magnetite, ferro-actinolite, allanite, zircon, fluorite and ilmenite are accessory minerals in these altered granites. The quartz decreases in volume to $0-2 \%$ in the syenitic episyenite and to $5-10 \%$ in the quartz alkali-feldspar syenitic episyenite over a distance of $20 \mathrm{~cm}$, after which hastingsite is also absent. The lower granite margin of the syenitic episyenite body includes a 10 -cm-wide zone enriched in quartz (segment a, Fig. 2).

\section{Episyenite}

The first episyenite body in the drill core (segment a, Fig. 2; Fig. 3e) has an average modal composition of a syenite and comprises $75-90 \%$ alkali feldspar, 1-15\% oligoclase, 1-9\% clinopyroxene and $0-2 \%$ quartz. The alkali feldspar forms irregularly shaped grey grains (average composition $\mathrm{An}_{<0.5} \mathrm{Ab}_{47} \mathrm{Or}_{53}$; Fig. 6a) with pink margins (Fig. 3j) that are surrounded by fine $(0.1-1 \mathrm{~mm}$ ) polygonal alkali feldspar (Fig. 5a). Oligoclase forms white granoblastic aggregates (grain size $0.1-0.5 \mathrm{~mm}$; Figs. $3 \mathrm{j}$ and $5 \mathrm{~b}$ ) with composition from $\mathrm{An}_{11} \mathrm{Ab}_{87} \mathrm{Or}_{2}$ to $\mathrm{An}_{22} \mathrm{Ab}_{76} \mathrm{Or}_{2}$ (Fig. 6a). The clinopyroxene is green hedenbergite to sodian augite with an average composition of $\mathrm{Wo}_{45} \mathrm{En}_{5} \mathrm{Fs}_{50}(\mathrm{Na}=0.075$ apfu; Fig. 8a). Rare 


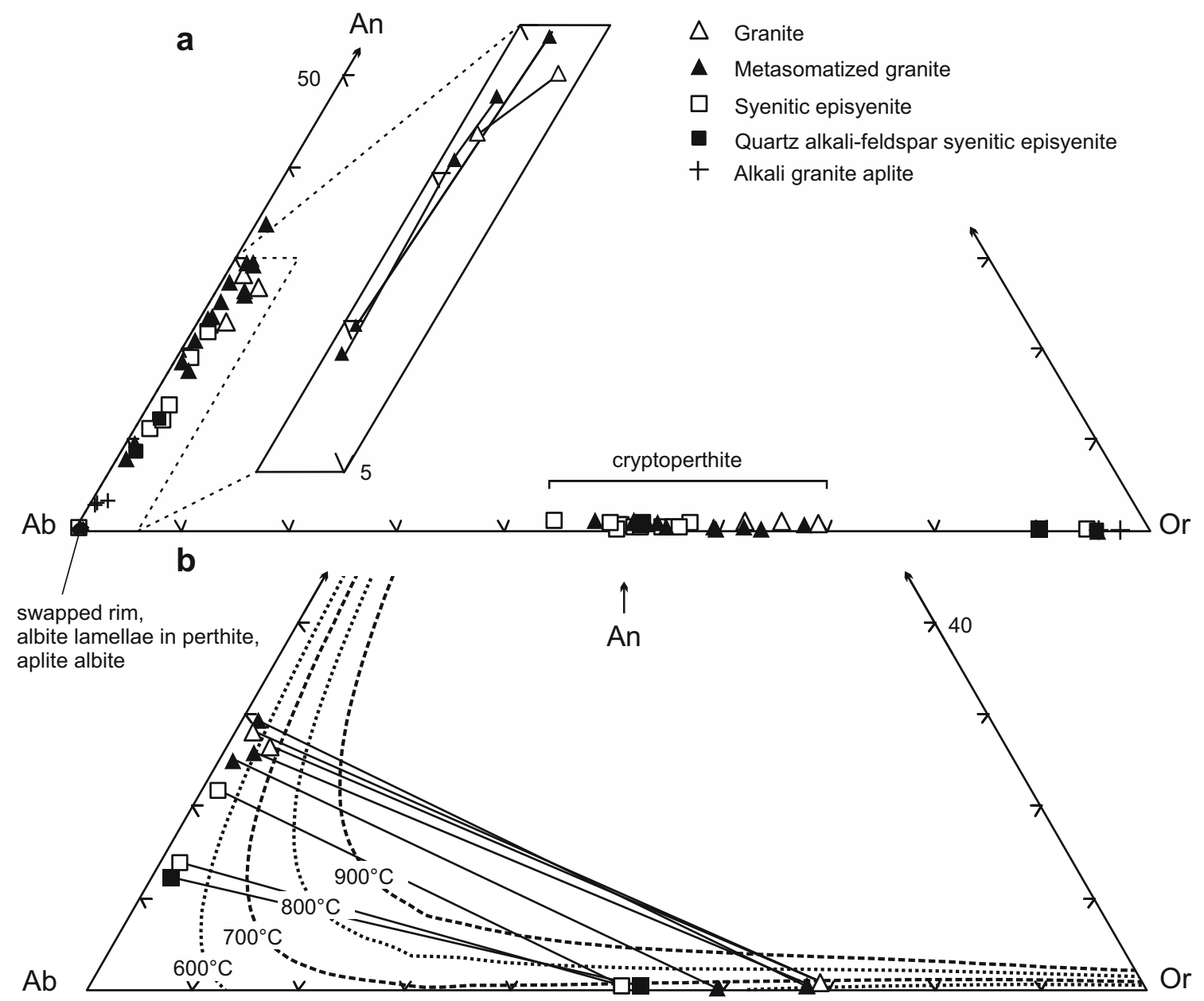

Fig. 6 a: Feldspar compositions for the granitic rocks and episyenites from the drill core plotted on the An-Ab-Or ternary. The inset illustrates analyses from compositionally zoned plagioclase grains (connected with solid line). b: Compositions of coexisting plagioclase and K-feldspar in the granites and episyenites. Dashed lines depict ternary feldspar solvi at 600-900 ${ }^{\circ} \mathrm{C}$ (Elkins and Grove 1990). Oligoclase $\left(\mathrm{An}_{27} \mathrm{Ab}_{69} \mathrm{Or}_{4}\right)$ and

quartz veinlets ( $\sim 2 \mathrm{~mm}$ thick) bordered by fine alkali feldspar crystals (Fig. 3j) are present as is quartz associated with augite; quartz in the marginal zones of this episyenite body may be strained and shows grain boundary migration and subgrain formation, whereas in the middle part of the body quartz records only weak undulatory extinction. In the upper marginal zone $(\sim 0.5 \mathrm{~m})$, plagioclase is scarce except for partially recrystallized and replaced grains included in alkali feldspars. The fine alkali feldspar crystals form polygonal, sometimes euhedral, grains $(0.1-1 \mathrm{~mm})$ within and along the grain margins of the larger alkali feldspar grains (Fig. 5a); polygonal alkali feldspar also surround plagioclase aggregates. Some alkali feldspar phenocrysts have been completely recrystallized into granoblastic aggregates (Fig. 5c). The fraction of this fine recrystallized feldspar is lower on the margins of the episyenite body than in the middle. Clinopyroxene is found as subidioblastic-idioblastic grains with quartz, rounded inclusions in alkali feldspar and xenoblastic interstitial alkali feldspar $\left(\mathrm{An}_{1} \mathrm{Ab}_{30} \mathrm{Or}_{69}\right)$ in the amphibole granite imply an equilibration temperature of ca. $675^{\circ} \mathrm{C}$ (Elkins and Grove 1990). Coexisting plagioclase and alkali feldspar in the metasomatized granites and especially in the episyenites show disequilibrium compositions and no equilibration temperatures can be calculated

masses, also within recrystallized alkali feldspar aggregates (Fig. 5c and d). K-feldspar has mostly recrystallized to turbid vein perthite (Fig. 5d), but some grains are water-clear (cryptoperthitic) under the microscope or show a finely exsolved braid perthite texture. Swapped albite rims are ubiquitous between $\mathrm{K}$-feldspar grains.

The accessory minerals of the first episyenite body (segment a, Fig. 2; Fig. 3e) include fine calcite found scarcely disseminated throughout the rock, and generally detected in the CL images. Titanite and magnetite are typically associated with augite. Small amounts of ferro-edenite and ferroactinolite are found in the upper marginal zone of the syenitic episyenite (Fig. 7). Ilmenite is found as exsolution lamellae in magnetite and as rare separate grains in relict plagioclase. Fine crystals of apatite are abundant. Fluorite is abundant in the upper marginal zone where it forms interstitial veinlets that host numerous grains of apatite. In this fluorite-rich upper marginal zone, FE-SEM analysis shows that apatite is found 
- Suomenniemi episyenites (Suikkanen and Rämö 2017) $\Delta$ Granite

$\Delta$ Metasomatized granite

- Syenitic episyenite

- Quartz alkali-feldspar syenitic episyenite Calcium amphiboles

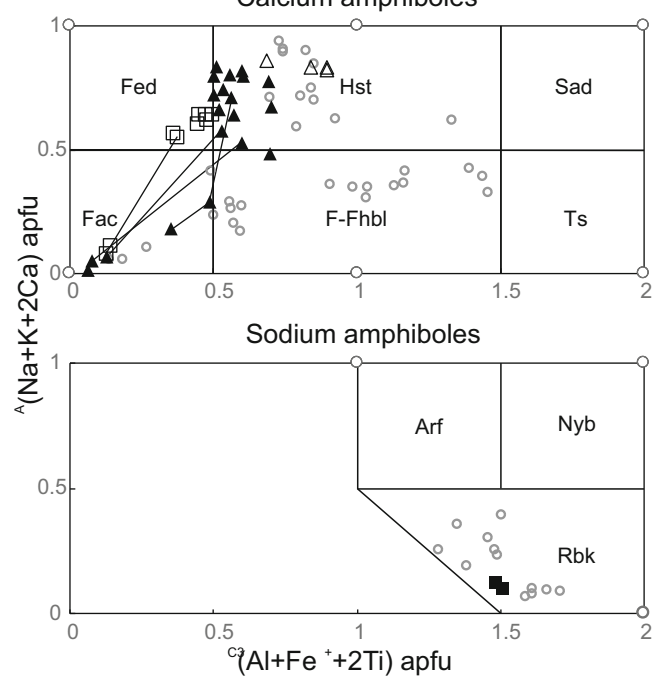

Fig. 7 Amphibole compositions of the granites and episyenites from the Suomenniemi drill core plotted on the classification diagrams of Hawthorne et al. (2012). Reference data from episyenite outcrop samples (Suikkanen and Rämö 2017) are also shown. Fields are according to the calculated amphibole formulae. Solid line connects analyses of adjacent amphiboles with a clear alteration relationship. Abbreviations: Arf $=$ Arfvedsonite, $\mathrm{Fac}=$ Ferro-actinolite, $\mathrm{Fed}=$ Ferroedenite, F-Fhbl $=$ Ferro-ferri-hornblende, Hst $=$ Hastingsite, $\mathrm{Nyb}=$ Nybøite, Rbk $=$ Riebeckite, Sad $=$ Sadanagaite, Ts $=$ Tschermakite

associated with monazite, xenotime and/or britholite-(Y). In addition, small fluorite grains are found in altered plagioclase on the marginal zones, whereas fluorite is rare in the middle of the episyenite body. Zircon is present throughout the body, and some zircon grains with dusty cores and recrystallized metamict margins can be found in the upper marginal zone.

The second episyenite body in the drill core (segment $b$, Fig. 2; Fig. 3g) has the modal composition of a quartz alkalifeldspar syenite, comprising $77-84 \%$ alkali feldspar, $1-2 \%$ plagioclase, 5-10\% quartz and 3-6\% clinopyroxene. Grey alkali-feldspar grains (average composition $\mathrm{An}_{1} \mathrm{Ab}_{47} \mathrm{Or}_{52}$ ) with pink margins are surrounded by aggregates of polygonal alkali feldspar crystals. Plagioclase is present as granoblastic aggregates with composition from albite $\left(\mathrm{An}_{9} \mathrm{Ab}_{90} \mathrm{Or}_{1}\right)$ to oligoclase $\left(\mathrm{An}_{12} \mathrm{Ab}_{86} \mathrm{Or}_{2}\right)$ (Fig. 6a). Grain boundaries are coated with hematite, which stains the rock dark red. The clinopyroxene is grass-green aegirine-augite $\left(\mathrm{Ae}_{42} \mathrm{Di}_{8} \mathrm{Hd}_{50}\right.$; Fig. 8a) and forms granular aggregates, xenoblastic masses, or idioblastic crystals associated with quartz. Aegirine-augite replaces quartz along grain boundaries in some samples (Fig. 5e). In addition, aegirine-augite close to the contact of this second episyenite body and the alkali granite aplite is $\mathrm{Mg}$ poor aegirine-augite with an average composition of $\mathrm{Ae}_{51} \mathrm{Di}_{2} \mathrm{Hd}_{47}$ (Fig. 8a). The fraction of quartz increases towards the lower end of the quartz alkali-feldspar syenitic episyenite body (Table 1). Quartz grains show variable deformation features, including undulatory extinction and deformation lamellae; quartz-quartz boundaries are sutured due to grain boundary migration. Riebeckite (Fig. 7) is found with aegirine-augite and more rarely interstitially, and accessory andradite forms small, round grains associated with aegirineaugite. Some perthite crystals are pervasively albitized. Calcite and riebeckite are also found disseminated in the rock, as fine inclusions in the coarsened perthite. This second episyenite body is relatively poor in magnetite compared to the syenitic episyenite, except for the altered granitic margins. At the weathered lower end of the drill core (Fig. 2), pseudomorphs of chlorite and quartz after clinopyroxene can be seen.

\section{Alkali granite aplite}

The alkali granite aplite is a pink rock that cuts the quartz alkalifeldspar syenitic episyenite body at the deep end of the drill core (segment b, Fig. 2; Fig. 3h). Albite ( $\sim \mathrm{Ab}_{99}$; Fig. $6 \mathrm{a}$ ) is the most abundant mineral in the aplite $(\sim 70 \%)$ and is present as fine subhedral to euhedral crystals (Fig. 5f) and interstitial grains; some coarse, twinned albite crystals in the marginal zone of the aplite have up to $3 \mathrm{~mol} \%$ An (Fig. 6a). Perthitic K-feldspar $(\sim 10 \%)$ is found as fine subhedral crystals and in interstitial spaces. Quartz ( $20 \%)$ is also interstitial (Fig. 5f), and ferromagnesian silicates are absent in the aplite. Perthite grains in the quartz alkali-feldspar syenitic episyenite adjacent to the alkali granite aplite are pervasively albitized (Fig. 5g).

\section{Whole-rock geochemistry}

Pertinent geochemical analyses of the episyenites and granites from the drill core are presented in Table 1 and complete geochemical data can be found in the electronic supplement (Online Resource 2). The $\mathrm{Na}_{2} \mathrm{O}$ contents of the drill-core episyenites are compared to the granites of the Suomenniemi complex (Rämö 1991; Suikkanen and Rämö 2017; this study) and the alkali granite aplite from the drill core in Fig. 9. The REE composition of the episyenites is shown relative to the chondritic composition and the granite average from the drill core ( $A v G r$ in Table 1) in Fig. 10.

The amphibole granite is ferroan, A-type, potassic (molar Na/ $\mathrm{K}=0.7)$, metaluminous $(\mathrm{A} / \mathrm{CNK}=0.94)$ and subalkaline $(\mathrm{NK} /$ $\mathrm{A}=0.86)$. The $\mathrm{Na}_{2} \mathrm{O}$ content of the granites is quite restricted,

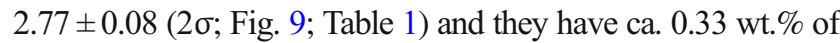
F. The REE patterns of the amphibole granites show little variation for the granite analyses from the drill core, but there is minor variation in total REE content $[703 \pm 81 \mathrm{ppm}(2 \sigma)$ in the average amphibole granite; Fig. 10a; Table 1].

The metasomatized granitic margins of the syenitic episyenite show minor $(0.5 \mathrm{wt}$. $\%)$ depletion in $\mathrm{K}_{2} \mathrm{O}$ and corresponding enrichment in $\mathrm{Na}_{2} \mathrm{O}$ compared to the amphibole granite. The quartz-rich metasomatic margin of the syenitic 


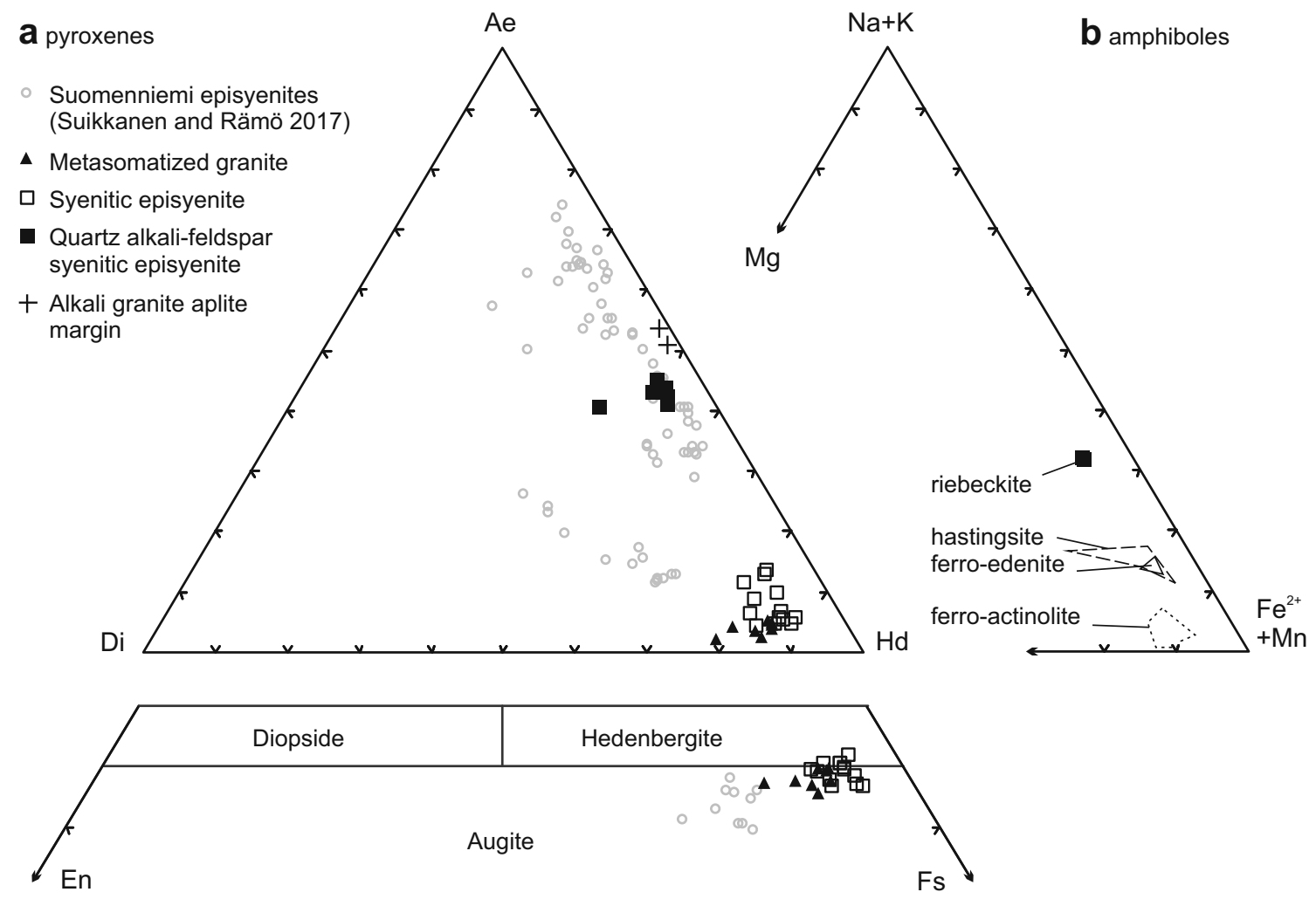

Fig. 8 a: Clinopyroxene compositions in the metasomatized granite, episyenites and the contact of between the alkali granite aplite and quartz alkali-feldspar syenitic episyenite plotted on the AegirineDiopside-Hedenbergite ternary $\left(\mathrm{Ae}=\mathrm{Na}+\mathrm{K}, \mathrm{Di}=\mathrm{Mg}\right.$ and $\mathrm{Hd}=\mathrm{Fe}^{2+}+$ $\mathrm{Mn}$ ). Reference data from episyenite outcrop samples (Suikkanen and

episyenite (Figs. 2, 3a; $104.75 \mathrm{~m}$ in Table 1) shows minor enrichment in $\mathrm{SiO}_{2}$ compared to the amphibole granite.

The episyenites mirror the ferroan character of the amphibole granites. They have variable $\mathrm{Na}_{2} \mathrm{O}$ (3.96-5.43 wt.\%; Fig. 9), are notably more sodic than the granites with molar $\mathrm{Na} / \mathrm{K}$ of $0.9-1.4$, and are marginally metaluminous $(\mathrm{NK} / \mathrm{A}=0.97-1.00$ and $\mathrm{A} / \mathrm{CNK}=0.79-0.91$; Table 1). The episyenites have 63.167.1 wt. $\% \mathrm{SiO}_{2}$, which is inversely proportional to the $\mathrm{Al}_{2} \mathrm{O}_{3}$ content (14.37-16.42 wt.\%). The episyenites are depleted in F compared to the granites $(0.04-0.17 \mathrm{wt} . \%)$. In addition, the syenitic episyenite is enriched in $\mathrm{CaO}$ compared to the amphibole granite, whereas the quartz alkali-feldspar syenitic episyenite is notably depleted in it. The quartz alkali-feldspar syenitic episyenite is enriched in $\mathrm{MgO}$ compared to the amphibole granite. The episyenites are generally slightly enriched in REE relative to the average amphibole granite, with the HREE enriched relative to the LREE (Fig. 10a and b). A notable (ca. 30\%) enrichment of total REE over the amphibole granite is shown by a margin sample of the syenitic episyenite body (Fig. 10b; $101.35 \mathrm{~m}$ in Table 1). The episyenites are slightly enriched in $\mathrm{Nb}$, $\mathrm{Sn}$, and $\mathrm{U}$, and depleted in $\mathrm{Rb}$ and $\mathrm{Li}$ relative to the amphibole granite. In addition, the syenitic episyenite is enriched in $\mathrm{Zn}$ relative to amphibole granite whereas $\mathrm{Zn}$ in the quartz alkalifeldspar syenitic episyenite is depleted.
Rämö 2017) are also shown. Compositions of calcic clinopyroxene are projected on the pyroxene quadrilateral following Morimoto et al. (1988). b: Drill core amphiboles shown for comparison on a $\mathrm{Na}+\mathrm{K}-\mathrm{Mg}-\mathrm{Fe}^{2+}+$ Mn ternary diagram

The alkali granite aplite is sodic (7.72 wt. $\% \mathrm{Na}_{2} \mathrm{O}$ and molar $\mathrm{Na} / \mathrm{K}=4.6)$, weakly peralkaline $(\mathrm{NK} / \mathrm{A}=1.01)$, metaluminous $(\mathrm{A} / \mathrm{CNK}=0.93)$, and very F-poor $(0.02$ wt.\% F; Table 1$)$. The aplite has a distinct chondrite-normalized REE pattern with HREE enriched relative to the LREE and a deep Eu-anomaly (Fig. 10a). It is also notably depleted in $\mathrm{Ba}, \mathrm{Rb}$ and $\mathrm{Sr}$, and has relatively high U-content (12 ppm).

\section{Discussion}

The mode of occurrence of the Suomenniemi complex episyenites as dike- or pod-like bodies (Fig. 1d) along shear zones is analogous to episyenites elsewhere (e.g. Cuney et al. 2012; Petersson et al. 2012). They also inherit many of the macrotextural features of their protolith granites (Fig. 3), yet lack the vuggy texture that is common in episyenites (e.g. Nishimoto et al. 2014). Moreover, hastingsite dehydration (Thomas 1982), granoblastic recrystallization of plagioclase (Fig. 5b; Fossen and Cavalcante 2017; Rosenberg and Stünitz 2003; see also Raith et al. 2014) and alkali feldspar compositions in the episyenites and their immediate margins (Fig. 6a) imply high temperature during the recrystallization stage $\left(>650^{\circ} \mathrm{C}\right.$ as dictated by the position of the Or-Ab binary 
Table 1 Geochemical composition of selected whole-rock samples from the Suomenniemi drill core. AvGr is the average amphibole granite composition used in mass balance calculations (Fig. 2; 72.7-92.9 m and 108.1-131.7 m, $n=10$ ). Depth denotes position in the drill core

\begin{tabular}{|c|c|c|c|c|c|c|c|c|c|c|}
\hline \multirow[b]{2}{*}{ Depth (m) } & \multirow[t]{2}{*}{$A v G r$} & \multirow[t]{2}{*}{$1 \sigma$} & \multicolumn{3}{|c|}{ Syenitic episyenite } & \multicolumn{2}{|c|}{ Metasomatized granite } & \multicolumn{2}{|c|}{ Qtz Afs syenitic episyenite } & \multirow{2}{*}{$\begin{array}{l}\text { Alkali granite } \\
\text { aplite } \\
135.45\end{array}$} \\
\hline & & & 101.35 & 102.60 & 104.15 & 100.90 & 104.75 & 134.80 & 139.20 & \\
\hline${ }^{\mathrm{a}} \mathrm{SG}$ & 2.67 & 0.03 & & 2.68 & & & & 2.66 & 2.70 & 2.65 \\
\hline \multicolumn{11}{|l|}{ wt. $\%$} \\
\hline $\mathrm{SiO}_{2}$ & 71.02 & 0.46 & 63.08 & 63.67 & 64.24 & 71.18 & 72.37 & 65.90 & 67.11 & 71.00 \\
\hline $\mathrm{TiO}_{2}$ & 0.33 & 0.03 & 0.50 & 0.36 & 0.38 & 0.31 & 0.32 & 0.40 & 0.38 & 0.13 \\
\hline $\mathrm{Al}_{2} \mathrm{O}_{3}$ & 13.02 & 0.18 & 16.42 & 16.41 & 15.50 & 12.92 & 12.41 & 15.27 & 14.37 & 15.39 \\
\hline $\mathrm{Fe}_{2} \mathrm{O}_{3}$ & 3.27 & 0.26 & 3.67 & 4.46 & 4.07 & 3.21 & 3.14 & 4.61 & 3.87 & 1.79 \\
\hline $\mathrm{MnO}$ & 0.05 & 0.01 & 0.06 & 0.07 & 0.09 & 0.04 & 0.06 & 0.04 & 0.07 & 0.02 \\
\hline $\mathrm{MgO}$ & 0.17 & 0.04 & 0.28 & 0.24 & 0.28 & 0.22 & 0.26 & 0.44 & 0.56 & 0.20 \\
\hline $\mathrm{CaO}$ & 1.49 & 0.09 & 2.00 & 1.74 & 2.36 & 1.48 & 1.42 & 0.99 & 0.92 & 0.55 \\
\hline $\mathrm{Na}_{2} \mathrm{O}$ & 2.77 & 0.08 & 4.60 & 5.16 & 4.83 & 3.48 & 3.23 & 5.43 & 3.96 & 7.72 \\
\hline $\mathrm{K}_{2} \mathrm{O}$ & 6.14 & 0.19 & 7.81 & 6.82 & 6.76 & 5.59 & 5.63 & 5.87 & 6.89 & 2.57 \\
\hline $\mathrm{P}_{2} \mathrm{O}_{5}$ & 0.05 & 0.00 & 0.12 & 0.03 & 0.03 & 0.05 & 0.05 & 0.03 & 0.12 & 0.02 \\
\hline $\mathrm{F}$ & 0.33 & 0.02 & 0.17 & 0.07 & 0.08 & 0.33 & 0.28 & 0.04 & 0.14 & 0.02 \\
\hline Total & 98.64 & & 98.71 & 99.03 & 98.62 & 98.81 & 99.17 & 99.02 & 98.39 & 99.41 \\
\hline $\mathrm{A} / \mathrm{CNK}^{\mathrm{b}}$ & 0.93 & 0.01 & 0.84 & 0.86 & 0.79 & 0.89 & 0.88 & 0.89 & 0.91 & 0.93 \\
\hline $\mathrm{NK} / \mathrm{A}^{\mathrm{c}}$ & 0.86 & 0.01 & 0.98 & 0.97 & 0.98 & 0.91 & 0.92 & 1.00 & 0.97 & 1.01 \\
\hline \multicolumn{11}{|l|}{ ppm } \\
\hline $\mathrm{La}$ & 148 & 18.5 & 160 & 158 & 168 & 151 & 112 & 156 & 158 & 59.5 \\
\hline $\mathrm{Ce}$ & 303 & 36.8 & 379 & 323 & 344 & 320 & 228 & 330 & 333 & 155 \\
\hline $\operatorname{Pr}$ & 35.0 & 4.09 & 48.5 & 37.7 & 40.9 & 38.2 & 27.1 & 39.3 & 39.6 & 17.4 \\
\hline $\mathrm{Nd}$ & 130 & 14.7 & 187 & 140 & 152 & 147 & 104 & 148 & 149 & 67.2 \\
\hline $\mathrm{Sm}$ & 22.8 & 2.35 & 36.4 & 25.3 & 27.5 & 27.6 & 19.5 & 26.8 & 27.2 & 15.1 \\
\hline $\mathrm{Eu}$ & 2.48 & 0.06 & 3.11 & 2.87 & 3.03 & 2.52 & 2.44 & 2.91 & 2.90 & 0.96 \\
\hline Gd & 20.1 & 2.07 & 32.9 & 22.4 & 24.2 & 25.2 & 17.5 & 23.8 & 24.7 & 14.5 \\
\hline $\mathrm{Tb}$ & 2.89 & 0.28 & 5.29 & 3.34 & 3.65 & 3.79 & 2.58 & 3.43 & 3.71 & 2.75 \\
\hline Dy & 16.1 & 1.48 & 31.9 & 18.9 & 21.0 & 22.0 & 14.7 & 19.3 & 21.6 & 18.2 \\
\hline Но & 3.20 & 0.29 & 6.65 & 3.79 & 4.26 & 4.45 & 2.94 & 3.86 & 4.37 & 3.92 \\
\hline $\mathrm{Er}$ & 9.21 & 0.83 & 20.2 & 11.0 & 12.8 & 13.0 & 8.42 & 11.1 & 12.6 & 12.8 \\
\hline $\mathrm{Tm}$ & 1.28 & 0.11 & 3.04 & 1.54 & 1.90 & 1.83 & 1.18 & 1.56 & 1.75 & 2.17 \\
\hline $\mathrm{Yb}$ & 8.06 & 0.67 & 19.6 & 9.80 & 12.8 & 11.4 & 7.44 & 9.85 & 11.0 & 15.6 \\
\hline $\mathrm{Lu}$ & 1.15 & 0.09 & 2.81 & 1.42 & 1.96 & 1.60 & 1.07 & 1.46 & 1.58 & 2.24 \\
\hline$\sum \mathrm{REE}$ & 703 & 81.4 & 935 & 759 & 817 & 770 & 549 & 778 & 790 & 388 \\
\hline $\mathrm{Ba}$ & 1058 & 95.2 & 1000 & 962 & 1020 & 1030 & 1110 & 800 & 1160 & 180 \\
\hline $\mathrm{Li}$ & 46.7 & 7.95 & 13.3 & 21.0 & 21.8 & 26.1 & 24.4 & 29.9 & 13.9 & 19.7 \\
\hline $\mathrm{Rb}$ & 259 & 13.7 & 261 & 178 & 202 & 207 & 216 & 105 & 172 & 39.0 \\
\hline $\mathrm{Sr}$ & 96.0 & 9.1 & 90.0 & 105.0 & 97.4 & 91.4 & 100.0 & 70.3 & 88.3 & 30.0 \\
\hline Th & 33.5 & 3.0 & 45.0 & 34.9 & 47.1 & 45.8 & 24.1 & 31.4 & 35.7 & 41.8 \\
\hline $\mathrm{U}$ & 5.20 & 0.60 & 10.5 & 5.50 & 8.70 & 8.70 & 4.90 & 12.3 & 10.2 & 12.0 \\
\hline $\mathrm{Zr}$ & 275 & 49.7 & 227 & 317 & 310 & 198 & 218 & 258 & 316 & 304 \\
\hline $\mathrm{Hf}$ & 9.56 & 1.56 & 6.80 & 11.1 & 11.5 & 7.10 & 7.60 & 9.50 & 10.7 & 10.9 \\
\hline $\mathrm{Y}$ & 62.2 & 7.19 & 102 & 47.6 & 67.6 & 74.7 & 55.3 & 44.2 & 60.8 & 36.8 \\
\hline $\mathrm{Nb}$ & 26.9 & 4.55 & 62.3 & 38.6 & 57.9 & 29.6 & 23.6 & 47.2 & 55.1 & 21.4 \\
\hline $\mathrm{Ta}$ & 1.49 & 0.42 & 6.30 & 2.80 & 4.10 & 1.90 & 1.20 & 3.10 & 3.00 & 3.20 \\
\hline $\mathrm{Sc}$ & 4.98 & 0.73 & 5.70 & 4.03 & 6.21 & 4.88 & 4.96 & 4.35 & 5.89 & 1.63 \\
\hline $\mathrm{Sn}$ & 3.53 & 0.34 & 15.5 & 9.10 & 15.0 & 8.40 & 5.00 & 7.10 & 11.5 & 3.00 \\
\hline $\mathrm{Zn}$ & 135 & 12.0 & 149 & 244 & 178 & 131 & 131 & 71.8 & 103 & 37.0 \\
\hline
\end{tabular}

${ }^{\mathrm{a}} \mathrm{SG}=$ specific gravity; ${ }^{\mathrm{b}} \mathrm{A} / \mathrm{CNK}=$ molar $\mathrm{Al}_{2} \mathrm{O}_{3} /\left(\mathrm{CaO}+\mathrm{Na}_{2} \mathrm{O}+\mathrm{K}_{2} \mathrm{O}\right) ;{ }^{\mathrm{c}} \mathrm{NK} / \mathrm{A}=$ agpaitic index $=$ molar $\left(\mathrm{Na}_{2} \mathrm{O}+\mathrm{K}_{2} \mathrm{O}\right) / \mathrm{Al}_{2} \mathrm{O}_{3}$ 


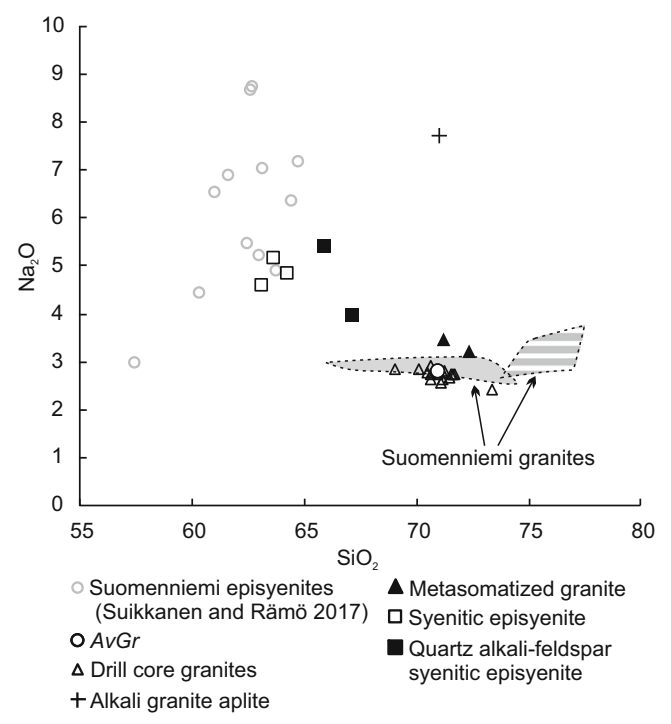

Fig. 9 Composition of the episyenites and granites from the Kirvesiemi drill core as displayed by variations in $\mathrm{SiO}_{2}$ and $\mathrm{Na}_{2} \mathrm{O}$. $\mathrm{AvGr}$ is the average amphibole granite composition from the drill core (Table 1). The compositions of episyenites from outcrops in the east-central part of the Suomenniemi complex (Suikkanen and Rämö 2017) are also shown. Shaded field shows the range of amphibole, amphibole-biotite and biotite granites and the striped field shows the compositions of the topaz granites from the Suomenniemi complex (Rämö 1991 and Suikkanen and Rämö 2017). $\mathrm{Na}_{2} \mathrm{O}$ content in the episyenites shows remarkable variability compared to the granites of the Suomenniemi complex. The alkali granite aplite has a distinct Na-rich composition

solvus; Smith and Parsons 1974). Such high temperatures are not normally observed for quartz-depletion in episyenites (300-450 ${ }^{\circ} \mathrm{C}$; e.g. Cathelineau 1986; Charoy and Pollard 1989), although they are common during prevalent metasomatic conditions of pervasive fenitization (Le Bas 1987). These high temperatures and observed ductile deformation pose a challenge to quartz-depletion in dike-like bodies, as permeability of a ductile shear zone is low, which makes large fluid fluxes untenable, thus impeding quartz dissolution and $\mathrm{Si}$ transport. The formation of these episyenite bodies may have required brittle-to-ductile evolution of the shear zones.

Due to extensive recrystallization, accurate reconstruction of the early history of these episyenites is challenging. For example, the timing of quartz-depletion is not easily constrained, nor is whether quartz was initially removed at all, although this ambiguity is not unique to the Suomenniemi complex episyenites (Petersson et al. 2014). It is possible that episyenitization and recrystallization of the drill core episyenites occurred intermittently over a prolonged time window (Cuney et al. 2012). The thermal history of the 1.644 Ga Suomenniemi complex is quite convoluted because of spatially connected $\sim 1.635$ Ga dike magmatism (Rämö 1991; Rämö and Mänttäri 2015) and subsequent, $\sim 1.63 \mathrm{Ga}$ (Heinonen et al. 2016) emplacement of the large Wiborg rapakivi granite batholith just south of the Suomenniemi complex (Fig. 1). It has been postulated that the emplacement of the Wiborg batholith caused uplift of the already consolidated
Suomenniemi complex, tilting it to the north-northwest (e.g. Rämö 1991). Thus, conditions promoting shearing and enhanced, high-temperature, fluid flow along the southernsoutheastern margin of the Suomenniemi complex existed at least 10-15 m.y. after its emplacement. As the source of the fluids is not obvious (unlike in most documented cases of fenitization, for example) and the temperatures involved are so high, some attention needs to be paid to the possible role of magmatic processes in the formation of these rocks.

\section{Episyenites or syenites - the role of magmatic processes}

In view of the coarse recrystallization textures (e.g. Fig. 5c) and absence of hastingsite in the episyenites, it is difficult to say with certainty whether hastingsite ever existed in these zones. Exsolution of fluid from a late melt would impede formation of hydrous magmatic phases, but it is hard to envision how fluid exsolution in a magma would produce the observed dike-like geometry of these bodies, unless they were intrusive dikes rather than those formed in situ. The absence of hydrous mafic phases can also be related to post-magmatic fluid-induced dehydration (Harlov et al. 2006) promoted by infiltration of fluid along quartz-depleted shear zones. Rims of alkali feldspar on the plagioclase-quartz boundaries, present in the dehydrated granites surrounding the episyenite bodies (as well as in the episyenites themselves), are typical of fluid-induced dehydration of granitic gneisses (Harlov et al. 2006; Safonov et al. 2012). It is possible that the augite formed by dehydration was metasomatically transformed to coarser augite (Fig. $5 \mathrm{c}$ and d; see also Vartiainen and Woolley 1976, p. 26) in the pervasively recrystallized episyenite; this coarsening would have led to the observed enrichment of the aegirine-component in clinopyroxene (Fig. 8).

The non-granoblastic alkali feldspar in the drill core episyenites (Fig. 3) has some similarities with textures presented by Plümper et al. (2017) for the larvikites from the Oslo rift, in which primary (magmatic), grey and non-turbid ternary alkali feldspar cores are overgrown by secondary, pink alkali feldspar (Fig. 3e and g). The alkali feldspar in the drill core episyenites and their clinopyroxene-bearing granitic margins seems to have more of the albite component on average than alkali feldspar in the amphibole granite (Fig. 6), having been compositionally equilibrated at some point during alteration. In the low-P, epizonal emplacement environment of the Suomenniemi complex (e.g. Rämö 1991), the intermediate and essentially Ca-free alkali feldspar composition (Fig. 6) and cryptoperthite texture do not necessarily imply magmatic feldspar, as the Or-Ab solvus (for alkali feldspar composition $\mathrm{Ab}_{50} \mathrm{Or}_{50}$ ) is reached ca. $120{ }^{\circ} \mathrm{C}$ below the wet granite solidus at 1 kbar (Johannes 1984; Smith and Parsons 1974). Granoblastic recrystallization of feldspar could have also begun already at the magmatic stage in the presence of a minor melt phase (Paterson et al. 2018; Vernon 2000). However, 


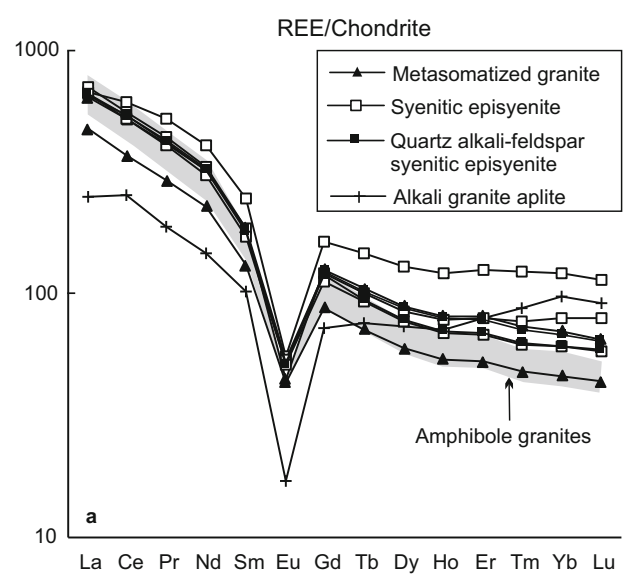

Fig. 10 Rare earth element composition of the metasomatized granites, episyenites and the alkali granite aplite in the drill core normalized to chondrite (a; McDonough and Sun 1995) and to average amphibole granite ( $\mathbf{b} ; A v G r$ in Table 1). Shaded fields show the range of the analyses that were used to calculate the $A v G r$ composition. The

sub-solidus recrystallization of feldspars to aggregates is common in fenites (e.g. Martin and Morogan 1985) and deformed feldspathic rocks (Raith et al. 2014). In addition, recrystallization led to Na-enrichment in episyenite feldspars, resulting in notable compositional disequilibrium between co-existing plagioclase and alkali feldspar (Fig. 6b), not entirely consistent with late-magmatic recrystallization (Vernon 2000).

The discussion above is consistent with two models for the formation of the syenitic rocks in the Suomenniemi complex:

Model 1: The high-temperature variants of the Suomenniemi complex episyenites are, in fact, magmatic syenites formed from F-depleted alkali feldspar-enriched Suomenniemi magmas at 1.644 Ga (e.g. Rämö 1991). Late, alkali feldspar-enriched magmas of the Suomenniemi complex, trapped below a crystalline cover degassed during retrograde boiling and intruded into the crystalline granitic cover. The dikes were then deformed at the late- or post-magmatic stage, resulting in recrystallization of feldspar. In this model, the wall rocks are altered due to hightemperature contact metasomatism and fluid-induced dehydration of mafic phases.

Model 2: The episyenites were formed by sub-solidus quartz-depletion, dehydration, and recrystallization of the amphibole granites in situ along brittle-ductile shear zones infiltrated by external or deuteric fluids. This model would be consistent for all types of syenites (Suikkanen and Rämö 2017) in the Suomenniemi complex.

Many of the features of the examined syenitic rocks are compatible with both models, which emphasizes that distinguishing high-temperature metasomatic rocks from magmatic rocks is not trivial. In the Suomenniemi case we prefer the sub-solidus shear zone model (Model 2), possibly driven by the significant thermal anomalies in the Suomenniemi complex area 10-15 m.y. after the emplacement of the complex. This is consistent with the textural similarities between the episyenite bodies and their host

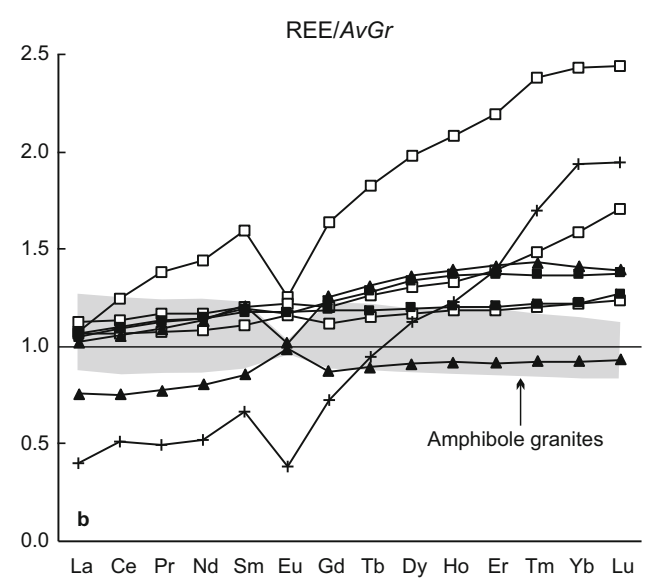

episyenites show minor enrichment of the HREE compared to $A v G r$. Analysis from the upper marginal zone of the syenitic episyenite body is enriched in the LREE and notably enriched in the HREE compared to $A v G r$. The alkali granite aplite has relatively low LREE and high HREE values typical of highly fractionated A-type granites

granites (Figs. 3, 4, 5; see also outcrop photographs in Suikkanen and Rämö 2017) and the chemical and mineralogical heterogeneity of the episyenites, including uneven distribution of quartz and plagioclase in the bodies (e.g. Fig. 3e and g).

\section{Mass transfer modeling of episyenite and dehydrated granite}

Mass transfer modeling allows assessment of the massvolume evolution of metasomatic rocks and may offer direct insight into the composition of the metasomatizing fluids. In the episyenites examined, however, the possible effects of sequential fluid imprints cannot be separated, because no intermediate steps are recognized. The average composition of 10 samples ( $A v G r$; Table 1), collected from the drill core at 72.8-98.9 $\mathrm{m}$ and 108.1-130.7 m (Fig. 2), was used for unaltered granite in the following mass balance calculations. The use of average of multiple geochemical analyses is a prerequisite for mass transfer models involving phaneritic rocks. Uncertainties are markedly larger if trace element data are considered, which is illustrated by the high standard deviation for $\mathrm{Zr}(275 \pm 50 \mathrm{ppm}, 2 \sigma)$ and $\mathrm{Nb}(27 \pm 5 \mathrm{ppm}, 2 \sigma)$ in our reference granite composition. In this case, any interpretation based on $\mathrm{Zr}$ or Nb immobility is bound to be inaccurate irrespective of whether these elements are immobile. In addition, significant volume loss may be caused by leaching of quartz during episyenitization. Hecht et al. (1999) proposed up to $40 \%$ volume decrease during episyenitization of granites of the northern Bohemian Massif, Germany. Rubie (1982) calculated a volume decrease of $0-20 \%$ for the fenites of the Kisingiri alkaline complex in western Kenya, the decrease depending on whether quartz was removed (into adjacent ijolitic magma) or reacted with the metasomatizing fluid to produce aegirine-augite in situ. Estimation of volume change 
requires assuming one or more elements to be immobile (Grant 1986) and/or assessment of physical constraints such as open pores (Appleyard and Woolley 1979; Nishimoto et al. 2014). Any component that participates in fluid-rock reactions (e.g., Al during albitization of plagioclase; Hövelmann et al. 2010) may be immobile in practice, if it is consumed in situ in crystallization of metasomatic phases.

Gains and losses of mobile components, as well as system volume change during episyenitization, were estimated utilizing the isocon method of Grant (1986). In this method, immobile components produce a straight line (isocon) through the origin on a $C_{A}-C_{O}$ diagram, where $C_{A}$ and $C_{O}$ are the concentrations of a component in altered and unaltered rock, respectively. For example, if $\mathrm{Al}$ is immobile, the isocon is defined by the equation $C_{A}=\left(A l_{A} / A l_{O}\right) C_{O}$ and components added during alteration plot above the line, whereas components removed plot below it. In addition, for zero mass change the isocon is defined as $C_{A}=C_{O}$ and for no system volume change the isocon is defined as $C_{A}=\left(\rho_{A} / \rho_{O}\right) C_{O}$, where $\rho_{A}$ and $\rho_{O}$ are the specific gravities of altered and unaltered rock, respectively.

Isocon diagrams, depicting gains and losses of components relative to constant mass or constant $\mathrm{Al}$ isocons, are shown in Fig. 11. Related mass balance calculations are given in the electronic supplement material (Online Resource 2). These constant $\mathrm{Al}$ and constant mass isocons approximate the maximum and minimum possible volume change (i.e. $\sim 20 \%$ and $\sim 0 \%$, respectively, Fig. 11b) during episyenitization, as interpreted from the range in isocon slopes and from the volume of quartz in the granite (20-30\%). The maximum volume decrease of $20 \%$ during episyenitization (mostly accounted for by quartz dissolution and subsequent compaction) as a prerequisite of $\mathrm{Al}$ immobility is neither supported nor disproved by geological evidence due to the extensive recrystallization. Although $\mathrm{Al}$ is certainly not immobile during metasomatic reactions concerning feldspars, most free $\mathrm{Al}$ would probably be incorporated into the neoformed feldspar that crystallizes extensively during the process (Rubie 1982). In addition, $\mathrm{Al}$ immobility is a common assumption or conclusion in studies of alkali metasomatism (e.g. Cuney et al. 2012; Hecht et al. 1999; Nishimoto et al. 2014; Rubie 1982; see also Dolejš and Wagner 2008). Thus, we believe that the immobile $\mathrm{Al}$ isocon can be used adequately to model mass transfer in this system. However, minor addition of $\mathrm{Al}$ to the episyenites cannot be ruled out due to the poorly defined isocons and the fact that $\mathrm{Al}$ solubility is somewhat increased relative to pure water in $\mathrm{NaCl}$-bearing solutions at conditions relevant to this study (400$600{ }^{\circ} \mathrm{C}$ and $0.5-2.0 \mathrm{kbar}$ ) (Walther 2001).

In the metasomatized granitic margin of the syenitic episyenite body, mass and volume would have remained constant during alteration as implied by an isocon defined by immobility of $\mathrm{Al}, \mathrm{Fe}, \mathrm{Ti}, \mathrm{Ca}, \mathrm{Mn}, \mathrm{Si}, \mathrm{Sr}$ and Ba (Fig. 11a). This rather robust model shows that $\mathrm{Na}\left(0.7 \mathrm{~g}\right.$ of $\mathrm{Na}_{2} \mathrm{O}$ per $100 \mathrm{~g}$ of original rock) was added to and $\mathrm{K}\left(0.5 \mathrm{~g}\right.$ of $\mathrm{K}_{2} \mathrm{O}$ per $\left.100 \mathrm{~g}\right)$ was removed from the metasomatized granite, which points to the interaction of the granite with a Na-bearing fluid. As for the episyenites, the immobile Al model implies that $\mathrm{Na}$ (a modest amount of ca. 0.9 $1.9 \mathrm{~g}$ of $\mathrm{Na}_{2} \mathrm{O}$ per $100 \mathrm{~g}$ of original rock) and $\mathrm{Sn}$ were added, whereas $\mathrm{Si}\left(10-21 \mathrm{~g}\right.$ of $\mathrm{SiO}_{2}$ per $100 \mathrm{~g}$ of original rock), $\mathrm{F}$ $(0.25 \mathrm{~g}), \mathrm{Ba}, \mathrm{Rb}$ and $\mathrm{Sr}$ were removed. As voluminous quartz vein formation is not observed in the host rocks of the episyenites, the dissolved $\mathrm{Si}$ would have been mainly removed along the shear zone. The quartz alkali-feldspar syenitic episyenite sample at $134.8-135.20 \mathrm{~m}$ (Fig. 11c), ca. $25 \mathrm{~cm}$ from the alkali granite aplite, obtained the most $\mathrm{Na}\left(1.9 \mathrm{~g} \mathrm{Na}_{2} \mathrm{O}\right.$ per $100 \mathrm{~g}$ of original rock) and lost $\mathrm{K}\left(1.1 \mathrm{~g}\right.$ of $\mathrm{K}_{2} \mathrm{O}$ per $\left.100 \mathrm{~g}\right)$ because it was albitized during the emplacement of the alkali granite aplite. In addition, $\mathrm{Mg}(0.2-0.35 \mathrm{~g}$ of $\mathrm{MgO}$ per $100 \mathrm{~g}$ of original rock) was added to the quartz alkali-feldspar syenitic episyenite, $\mathrm{Ca}$ (ca. $0.5 \mathrm{~g}$ of $\mathrm{CaO}$ per $100 \mathrm{~g}$ ) was removed from the quartz alkali-feldspar syenitic episyenites (Fig. 11c and d), and $\mathrm{Ca}(0.5 \mathrm{~g}$ of $\mathrm{CaO}$ per $100 \mathrm{~g})$ was added to sample from the lower margin of the syenitic episyenite.

The minor LREE enrichment and notable HREE enrichment exhibited by the fluorite-bearing margin of the syenitic episyenite (Table 1; Fig. 10) suggests potential for rare earth mineralization. FE-SEM analysis indicates that the enrichment is explained by formation of monazite (LREE), as well as xenotime and britholite-(Y) (HREE). It is probably not a coincidence that the REE enrichment is associated with notable occurrence fluorite, as fluorine may play a role in mobilization of REE or deposition of these elements from a $\mathrm{H}_{2} \mathrm{O}-\mathrm{Cl}$ solution (e.g. Midgisov and Williams-Jones 2014).

\section{Consolidation of a genetic model}

In view of the petrographic, mineral chemical and geochemical data on the drill-core samples, we propose a three-stage sequence for the formation the syenitic rocks of the Suomenniemi complex (Fig. 12). At an initial stage, brittle shear zones were formed that channeled fluids, promoting quartz-depletion and possibly some alkali metasomatism. While this initial brittle stage is largely hypothetical, the low permeability of ductile shear zones can impede major quartz dissolution and subsequent Si transport. This stage would have resembled the formation of the "type-1" episyenites of Suikkanen and Rämö (2017). It is significant that quartz was not completely removed from the episyenite bodies at this stage (Fig. 3), as implied by the presence of subhedral quartz especially in the quartz alkali-feldspar syenitic episyenite body in the drill core. If quartz depletion was controlled by fluid-rock ratio that was enhanced by fracturing, the quartzbearing sections may have been left more intact and stayed relatively impermeable.

In the subsequent stage, infiltration of high-temperature Na-bearing fluid along partially quartz-depleted shear zones resulted in extensive recrystallization of feldspars and dehydration of amphibole and biotite. At least minor quartz- 


$\begin{array}{ll}\text { Multipliers used: } \\ \mathrm{Si} & =0.25 \\ \mathrm{Ti} & =10 \\ \mathrm{Al} & =1 \\ \mathrm{Fe} & =1 \\ \mathrm{Mn} & =10 \\ \mathrm{Mg} & =10 \\ \mathrm{Ca} & =1 \\ \mathrm{Na} & =1 \\ \mathrm{~K} & =1 \\ \mathrm{P} & =10 \\ \mathrm{~F} & =10 \\ \mathrm{Ba} & =0.01 \\ \mathrm{Rb} & =0.05 \\ \mathrm{Sr} & =0.1 \\ \mathrm{LREE} & =0.02 \\ \mathrm{HREE} & =0.2 \\ \mathrm{U} & =1 \\ \mathrm{Zn} & =0.05 \\ \mathrm{Sn} & =1\end{array}$
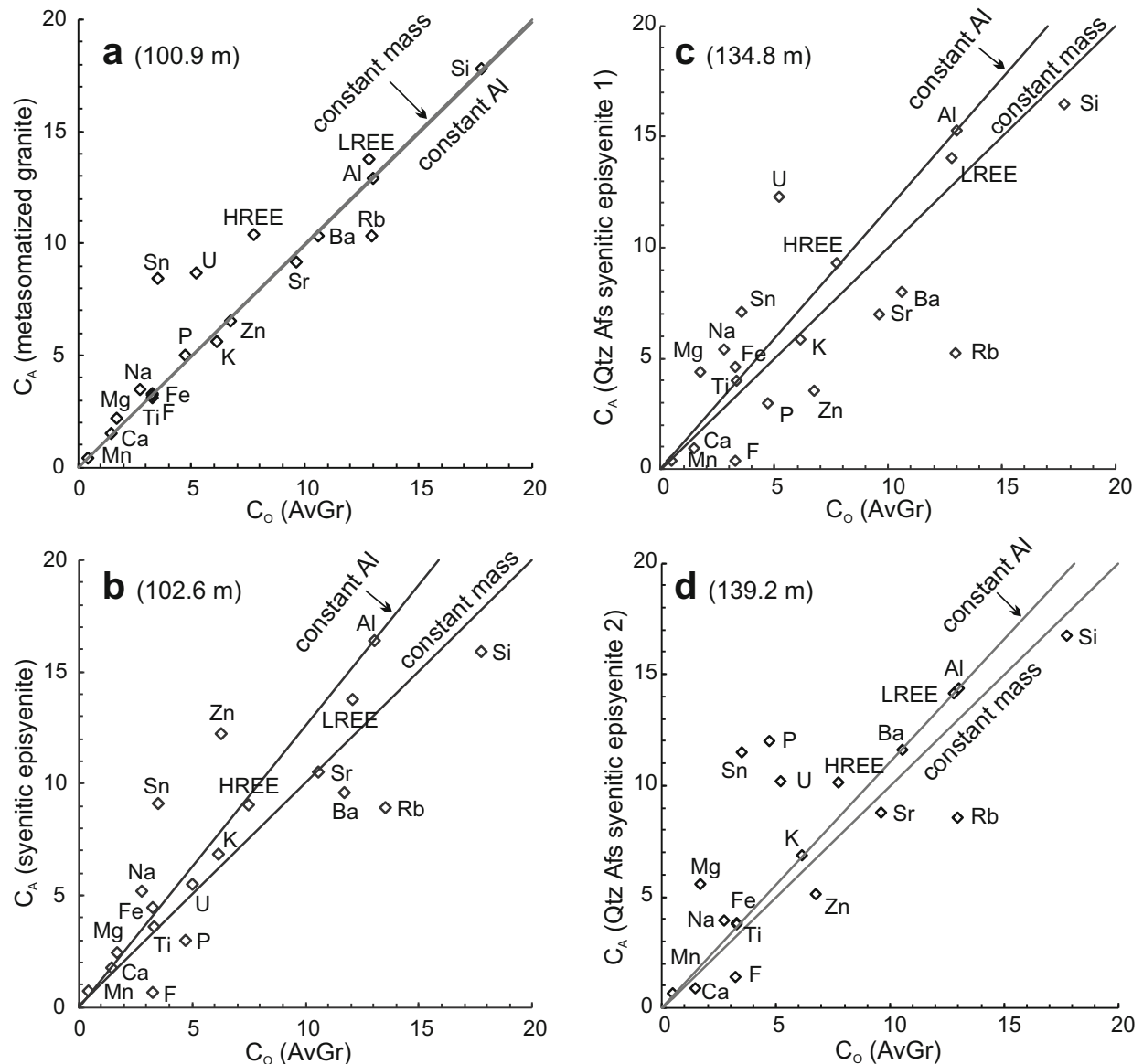

Fig. 11 Isocon diagrams depicting gains and losses of components in alteration from average amphibole granite composition ( $A v G r$; Table 1) to metasomatized granite (a), syenitic episyenite (b), and quartz alkalifeldspar syenitic episyenite $(\mathbf{c}-\mathbf{d})$. The two isocons are calculated assuming constant mass and immobile Al. Major elements (as oxides) and $\mathrm{F}$ are in wt. \%, and trace elements are in ppm. The concentrations are scaled by the multipliers shown left of panels. a: Alteration from amphibole granite to metasomatized augite-bearing granite has resulted in addition of $\mathrm{Na}_{2} \mathrm{O}(0.7 \mathrm{~g}$ per $100 \mathrm{~g}$ of original rock $)$ and minor decrease in $\mathrm{K}_{2} \mathrm{O}$ ( $0.5 \mathrm{~g}$ per $100 \mathrm{~g}$ of original rock). Most major and trace elements shown lie on the near-parallel isocons defined constant mass and constant Al. Assuming constant Al, the volume factor is $\sim 1.01$ (1\% volume increase). b: The slopes defined by different components do not show

depletion occurred by replacement (by clinopyroxene for example, Fig. 5e). Clinopyroxene was coarsened and enriched in Na within the episyenitic zones. Feldspars were partially recrystallized to granoblastic aggregates within the episyenite bodies (Fig. 5a and b; Raith et al. 2014). The plagioclase aggregates are mostly absent in samples from the upper, Krich (Table 1) margin of the syenitic episyenite body (Fig. 2; segment a). This mineralogical and geochemical heterogeneity along the traverse of the episyenite body is characteristic of the metasomatic process. Lastly, the alkali granite aplite intruded the quartz alkali-feldspar syenitic episyenite and caused albitization of its immediate margins.

The fluid or fluids related to this process may be magmatic and related to the rapakivi granite or mafic clustering behavior, which implies that most components were mobile during the alteration from amphibole granite to the syenitic episyenite. $\mathrm{Fe}, \mathrm{Mn}, \mathrm{Mg}$ and $\mathrm{Ca}$ plot close to the isocon defined by immobile $\mathrm{Al}$. Assuming immobile $\mathrm{Al}, \mathrm{Na}_{2} \mathrm{O}$ was added to the system $(1.3 \mathrm{~g}$ per $100 \mathrm{~g}$ of original rock), whereas $\mathrm{SiO}_{2}(21 \mathrm{~g})$ and $\mathrm{K}_{2} \mathrm{O}(0.8 \mathrm{~g})$ were removed during formation of the syenitic episyenite body. Assuming constant $\mathrm{Al}$, the volume factor is $\sim 0.79$, which equates to $21 \%$ volume decrease during episyenitization. c-d: Assuming constant Al, the quartz alkali-feldspar syenitic episyenite samples show volume factors of $0.86-0.09$, or 9 $14 \%$ volume decrease. The constant Al-model implies they have obtained $0.8-1.86 \mathrm{~g} / 100 \mathrm{~g}$ of $\mathrm{Na}_{2} \mathrm{O}$, and lost $10-15 \mathrm{~g} \mathrm{SiO}_{2}$ and $0.6 \mathrm{~g}$ $\mathrm{CaO}$. In addition, sample $\mathbf{c}$ was albitized during the emplacement of the alkali granite aplite and as a result show depletion of $\mathrm{K}_{2} \mathrm{O}(-1.1 \mathrm{~g} / 100 \mathrm{~g})$

magmatism in the area, though involvement of meteoric water is also possible (e.g. Cuney et al. 2012). Fluids related to a distinct alkaline intrusion below the present erosion level were suggested by Suikkanen and Rämö (2017), based on the similarities of the outcrop samples with fenites. This possibility cannot be excluded. The alkali granite aplite that cuts the quartz alkali-feldspar syenitic episyenite indicate an undiscovered alkaline magma system (e.g. peralkaline granite) below the present erosional level of the complex. This weakly peralkaline, Na-rich and Fpoor aplite does not seem to be related to the late granites of the Suomenniemi complex or the Wiborg batholith, those being topaz-bearing peraluminous granites (Lukkari et al. 2009; Rämö 1991). 


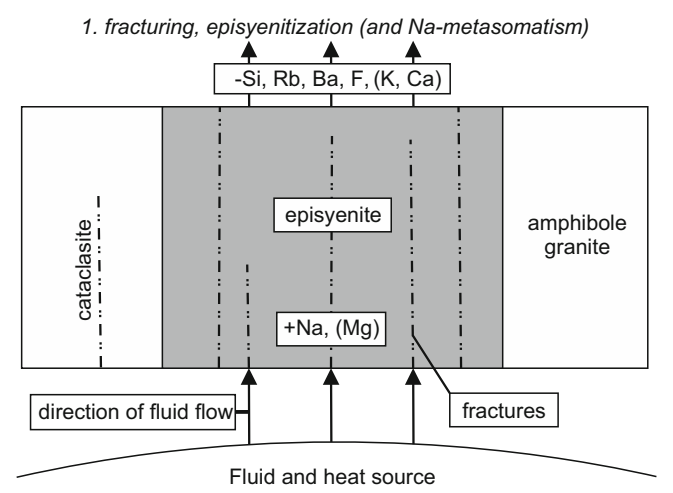

2. fluid-assisted dehydration and annealing of shear zone 3. emplacement of the alkali granite aplite and albitization

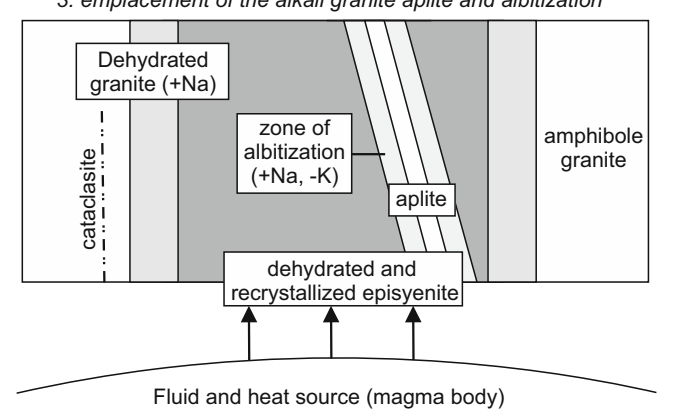

Fig. 12 Genetic model of the formation of the episyenites in the Suomenniemi drill core. 1. NW-striking fracture zones form within the Suomenniemi granite. Quartz is partially dissolved in an infiltrating Nabearing fluid and removed along the quartz-depleted columns. 2. Hightemperature $\left(>650^{\circ} \mathrm{C}\right)$ fluid-assisted annealing the episyenite zone and its granitic margin cause breakdown of hydrous mafic minerals and recrystallization of feldspars. 3. Alkali granite aplite is emplaced and causes additional albitization of the episyenite

It is notable that the metasomatic minerals in the augite syenitic episyenite and its granitic margins are not particularly Na-rich, except for the feldspar. The release of Al from plagioclase and amphibole (and possible minor influx of $\mathrm{Al}$ ) may result in preferential crystallization of feldspar and augite over aegirine-augite. This observation implies that the fluid present during formation of the syenitic episyenite, while sodic, was not strongly peralkaline. The presence of riebeckite and aegirine-augite instead of augite in the quartz alkali-feldspar syenitic episyenite may reflect the presence of a more sodic or more oxidizing fluid. The mineralogy of the altered rocks is not expected to mirror fluid evolution exactly, as varying sections of the fluid channel may have been active at different times promoted by formation of metasomatic fabrics with relatively low permeability (Petersson et al. 2012).

\section{Conclusions}

Augite/aegirine-augite episyenites have formed in response to one or more stages of alteration related to infiltration of Nabearing fluids through amphibole granite of the epizonal, $1.644 \mathrm{Ga}$ Suomenniemi rapakivi granite complex. This process was possibly initiated by fracturing associated with quartz dissolution, followed by high-temperature, nearsolidus (e.g. $650-770{ }^{\circ} \mathrm{C}$ ) recrystallization leading to fluidinduced dehydration of hastingsite and biotite, and partial recrystallization of feldspars into granoblastic polygonal aggregates. Less than $50 \mathrm{~cm}$ of dehydrated, augite-bearing granite surround the quartz-depleted zones. Based on geochemical mass balance modeling, minor amounts of $\mathrm{Na}$ were introduced into the rocks; in the process, the quartz-depleted variants suffered up to $20 \%$ decrease in system volume due to quartz dissolution and compaction. The fluids responsible for the quartz-depletion and annealing may have been related to the profuse, ca. 1.635-1.630 Ga magmatism that followed the emplacement of the Suomenniemi complex.

Our new textural and geochemical data based on the novel diamond drill core, along with observations published thus far, indicate that diverse episyenitic rocks can form by metasomatic, fenitization-style processes in epizonal A-type granite complexes. Extensive field and petrographic observations are critical in recognition of high-temperature episyenites that may resemble magmatic syenites because of pervasive alteration and coarse recrystallization textures, abrupt transition from protolith to altered rock and presence of hypersolvus alkali feldspar. Thus far, the significance of metasomatism in the petrogenesis of syenitic rocks in A-type complexes may have been underestimated.

Acknowledgments We gratefully acknowledge Mr. Lassi Pakkanen (Geological Survey of Finland) for operating the electron microprobe, Dr. Sari Lukkari (Geological Survey of Finland) for help with the FESEM work, Mr. Pasi Heikkilä (University of Helsinki) for the XRF analyses and musings on the method, Mr. Radoslaw Michallik (University of Helsinki) for help with sample preparation, and Dr. Dina Schultze (University of Helsinki) for sharing her expertise in CL microscopy. Constructive reviews of Prof. Uwe Altenberger (University of Potsdam) and Prof. Christoph Hauzenberger (University of Graz) improved the manuscript considerably. We also wish to thank Prof. Tom Andersen (University of Oslo) for fruitful discussions and comments on an early version of the manuscript as well as Prof. David Whipp (University of Helsinki) for checking the English of the manuscript. This work was funded by the K.H. Renlund Foundation (grant to O.T.R.).

Funding Information Open access funding provided by University of Helsinki including Helsinki University Central Hospital.

Open Access This article is distributed under the terms of the Creative Commons Attribution 4.0 International License (http:// creativecommons.org/licenses/by/4.0/), which permits unrestricted use, distribution, and reproduction in any medium, provided you give appropriate credit to the original author(s) and the source, provide a link to the Creative Commons license, and indicate if changes were made.

\section{References}

Akinfiev NN, Diamond LW (2009) A simple predictive model of quartz solubility in water-salt- $\mathrm{CO}_{2}$ systems at temperatures up to $1000^{\circ} \mathrm{C}$ and pressures up to 1000MPa. Geochim Cosmochim Acta 73:1597-1608 
Appleyard EC, Woolley AR (1979) Fenitization: An example of the problems of characterizing mass transfer and volume changes. Chem Geol 26:1-15

Cathelineau M (1986) The hydrothermal alkali metasomatism effects on granitic rocks: Quartz dissolution and related subsolidus changes. J Petrol 27:945-965

Charoy B, Pollard PJ (1989) Albite-rich, silica-depleted metasomatic rocks at Emuford, Northeast Queensland; mineralogical, geochemical, and fluid inclusion constraints on hydrothermal evolution and tin mineralization. Econ Geol 84:1850-1874

Cuney M, Emetz A, Mercadier J, Mykchaylov V, Shunko V, Yuslenko A (2012) Uranium deposits associated with Na-metasomatism from central Ukraine: A review of some of the major deposits and genetic constraints. Ore Geol Rev 44:82-106

Dolejš D, Wagner T (2008) Thermodynamic modeling of non-ideal mineral-fluid equilibria in the system $\mathrm{Si}-\mathrm{Al}-\mathrm{Fe}-\mathrm{Mg}-\mathrm{Ca}-\mathrm{Na}-\mathrm{K}-$ $\mathrm{H}-\mathrm{O}-\mathrm{Cl}$ at elevated temperatures and pressures: Implications for hydrothermal mass transfer in granitic rocks. Geochim Cosmochim Acta 72:526-553

Elkins LT, Grove TL (1990) Ternary feldspar experiments and thermodynamic models. Am Mineral 75:544-559

Elliott BA, Peck WH, Rämö OT, Vaasjoki M, Nironen M (2005) Magmatic zircon oxygen isotopes of $1.88-1.87 \mathrm{Ga}$ orogenic and $1.65-1.54 \mathrm{Ga}$ anorogenic magmatism in Finland. Mineral Petrol 85:223-241

Fossen H, Cavalcante GCG (2017) Shear zones - A review. Earth Sci Rev 171:434-455

González-Casado JM, Caballero JM, Casquet C, Galindo C, Tornos F (1996) Palaeostress and geotectonic interpretation of the Alpine Cycle onset in the Sierra del Guadarrama (eastern Iberian Central System), based on evidence from episyenites. Tectonophysics 262:213-229

Grant JA (1986) The isocon diagram; a simple solution to Gresens' equation for metasomatic alteration. Econ Geol 81:1976-1982

Grew ES, Locock AJ, Mills SJ, Galuskina IO, Galuskin EV, Hålenius U (2013) Nomenclature of the garnet supergroup. Am Mineral 98:785-811

Harlov DE, Johansson L, Van Den Kerkhof A, Förster H-J (2006) The Role of Advective Fluid Flow and Diffusion during Localized, Solid-State Dehydration: Söndrum Stenhuggeriet, Halmstad, SW Sweden. J Petrol 47:3-33

Hecht L, Thuro K, Plinninger R, Cuney M (1999) Mineralogical and geochemical characteristics of hydrothermal alteration and episyenitization in the Königshain granites, northern Bohemian Massif, Germany. Int J Earth Sci 88:236-252

Heinonen A, Mänttäri I, Rämö OT, Andersen T, Larjamo K (2016) A priori evidence for zircon antecryst entrainment in megacrystic Proterozoic granites. Geology 44:227-230

Hövelmann J, Putnis A, Geisler T, Schmidt BC, Golla-Schindler U (2010) The replacement of plagioclase feldspars by albite: observations from hydrothermal experiments. Contrib Mineral Petrol 159:43-59

Johannes W (1984) Beginning of melting in the granite system Qz-OrAb-An-H2O. Contrib Mineral Petrol 86:264-273

Le Bas MJ (1987) Nephelinites and carbonatites. Geol Soc Lond, Spec Publ 30:53-83

Leroy J (1978) The Margnac and Fanay uranium deposits of the La Crouzille District (western Massif Central, France); geologic and fluid inclusion studies. Econ Geol 73:1611-1634

Locock AJ (2014) An Excel spreadsheet to classify chemical analyses of amphiboles following the IMA 2012 recommendations. Comput Geosci 62:1-11. https://doi.org/10.1016/j.cageo.2013.09.011

Lukkari S, Thomas R, Haapala I (2009) Crystallization of the Kymi topaz granite stock within the Wiborg rapakivi granite batholith, Finland: Evidence from melt inclusions. Can Mineral 47:1359-1374

Martin RF, Morogan V (1985) Mineralogy and partial melting of fenitized crustal xenoliths in the Oldoinyo Lengai carbonatitic volcano, Tanzania. Am Mineral 70:1114-1126
McDonough WF, Sun S (1995) The composition of the Earth. Chem Geol $120: 223-253$

Midgisov AA, Williams-Jones AE (2014) Hydrothermal transport and deposition of the rare earth elements by fluorine-bearing aqueous fluids. Mineral Deposita 49:987-997

Nishimoto S, Yoshida H, Asahara Y, Tsuruta T, Ishibashi M, Katsuta N (2014) Episyenite formation in the Toki granite, central Japan. Contrib Mineral Petrol 167:960-971

Paterson SR, Ardill K, Vernon R, Žák J (2018) A review of mesoscopic magmatic structures and their potential for evaluating the hypersolidus evolution of intrusive complexes. J Struct Geol. https://doi.org/10.1016/j.jsg.2018.04.022

Petersson J, Fallick AE, Broman C, Eliasson T (2014) Imprints of multiple fluid regimes on episyenites in the Bohus granite, Sweden. Lithos 196-197:99-114

Petersson J, Stephens MB, Mattsson H, Möller C (2012) Albitization and quartz dissolution in Paleoproterozoic metagranite, central Sweden - Implications for the disposal of spent nuclear fuel in a deep geological repository. Lithos 148:10-26

Plümper O, Botan A, Los C, Liu Y, Malthe-Sørenssen A, Jamtveit B (2017) Fluid-driven metamorphism of the continental crust governed by nanoscale fluid flow. Nat Geosci 10:685

Raith MM, Mahapatro SN, Upadhyay D, Berndt J, Mezger K, Nanda JK (2014) Age and P-T evolution of the Neoproterozoic Turkel Anorthosite Complex, Eastern Ghats Province, India. Precambrian Res 254:87-113

Rämö OT (1991) Petrogenesis of the Proterozoic rapakivi granites and related basic rocks of southeastern Fennoscandia: $\mathrm{Nd}$ and $\mathrm{Pb}$ isotopic and general geochemical constraints. Geol Surv Finland Bull 355:161

Rämö OT, Mänttäri I (2015) Geochronology of the Suomenniemi rapakivi granite complex revisited: Implications of point-specific errors on zircon U-Pb and refined $\lambda_{87}$ on whole-rock Rb-Sr. Bull Geol Soc Finl 87:25-45

Rosenberg CL, Stünitz H (2003) Deformation and recrystallization of plagioclase along a temperature gradient: an example from the Bergell tonalite. J Struct Geol 25:389-408

Rubie DC (1982) Mass transfer and volume change during alkali metasomatism at Kisingiri, Western Kenya. Lithos 15:99-109

Safonov OG, Kovaleva EI, Kosova SA, Rajesh HM, Belyanin GA, Golunova MA, Van Reenen DD (2012) Experimental and petrological constraints on local-scale interaction of biotite-amphibole gneiss with $\mathrm{H} 2 \mathrm{O}-\mathrm{CO} 2-(\mathrm{K}$, $\mathrm{Na}) \mathrm{Cl}$ fluids at middle-crustal conditions: Example from the Limpopo Complex, South Africa. Geosci Front 3:829-841

Schneider CA, Rasband WS, Eliceiri KW (2012) NIH Image to ImageJ: 25 years of image analysis. Nat Methods 9:671

Smith P, Parsons I (1974) The alkali-feldspar solvus at 1 kilobar watervapour pressure. Mineral Mag 39:747-767

Suikkanen E, Rämö OT (2017) Metasomatic alkali-feldspar syenites (episyenites) of the Proterozoic Suomenniemi rapakivi granite complex, southeastern Finland. Lithos 294-295:1-19

Thomas WM (1982) Stability relations of the amphibole hastingsite. Am J Sci 282:136-164

Walther JV (2001) Experimental determination and analysis of the solubility of corundum in 0.1 and $0.5 \mathrm{~m} \mathrm{NaCl}$ solutions between 400 and $600^{\circ} \mathrm{C}$ from 0.5 to 2.0 kbar. Geochim Cosmochim Acta 65:2843-2851

Vartiainen H, Woolley AR (1976) The petrography, mineralogy and chemistry of the fenites of the Sokli carbonatite intrusion, Finland. Geol Surv Finland Bull 280:87

Vernon R (2000) Review of microstructural evidence of magmatic and solid-state flow. Vis Geosci Ann Arch 5:1-23

Publisher's note Springer Nature remains neutral with regard to jurisdictional claims in published maps and institutional affiliations. 